Portland State University

PDXScholar

7-6-2021

\title{
Rowing Concerns: Collaborative Governance and Stakeholder Determination in the Central Oregon's Deschutes Basin
}

Noel Vineyard

Portland State University

Follow this and additional works at: https://pdxscholar.library.pdx.edu/open_access_etds

Part of the Geography Commons, and the Water Resource Management Commons Let us know how access to this document benefits you.

Recommended Citation

Vineyard, Noel, "Rowing Concerns: Collaborative Governance and Stakeholder Determination in the Central Oregon's Deschutes Basin" (2021). Dissertations and Theses. Paper 5735.

https://doi.org/10.15760/etd.7606

This Thesis is brought to you for free and open access. It has been accepted for inclusion in Dissertations and Theses by an authorized administrator of PDXScholar. Please contact us if we can make this document more accessible: pdxscholar@pdx.edu. 
Rowing Concerns: Collaborative Governance and Stakeholder Determination in the Central Oregon's Deschutes Basin

by

Noel Vineyard

A thesis submitted in partial fulfillment of the requirements for the degree of

\author{
Master of Science \\ in \\ Geography
}

\author{
Thesis Committee: \\ Alida Cantor, Chair \\ Hunter Shobe \\ Aaron Roussell
}

Portland State University

Spring 2021 


\begin{abstract}
In 2019, a coalition of irrigation districts in central Oregon's Deschutes Basin submitted the Deschutes Basin Habitat Conservation Plan to the US Department of Fish and Wildlife. This Habitat Conservation Plan purported to have been constructed through a collaborative governance structure between the irrigation districts and various community stakeholders who all had interests in basin management, however segments of the Basin's river recreation community began to raise concerns that their voices were not included. The purpose of this research was to investigate how stakeholder status in the Deschutes Basin is created through collaborative water governance processes like development of the Habitat Conservation Plan, and what role competing senses of place might have in this process. To explore these questions, I conducted 15 semi-structured interviews were conducted with irrigation district representatives, government officials, NGO representatives, recreation industry professionals and others involved with collaborative water governance in the region. Stakeholder status in Deschutes Basin water collaboratives appears to be a two-step, "Interest-Action" process where a community group first must demonstrate a property interest in the management of the Basin's water, and then successfully participate in collaborative efforts while navigating political, material and place-based obstacles to participation. The assertion of property interests appears to be strongly tied to a community group's normative place-meanings of the Deschutes Basin, and differing senses of place also appeared to mediate a group's willingness and motivation to participate in collaborative efforts. The important role that
\end{abstract}


geography places in both phases of this process highlights the important role that geographers must play in improving collaborative processes in the future. 


\section{Acknowledgements}

This research would not have been possible without the work of my brilliant advisor, Dr. Alida Cantor. Under her mentorship and guidance, I was able to build out a skillset and a passion for this kind of work that will shape the work I do forever. She has set the bar exceedingly high for what it means to mentor a graduate student and for that I am exceptionally grateful.

I am also grateful to my other excellent committee members Hunter Shobe and Aaron Roussell. Both went above and beyond helping me puzzle through the theory of this project, gave me space in their classes to try out new ideas and encouraged me to examine my thinking in new, exciting, and challenging ways.

I must also acknowledge that this process has been a considerable family effort. Thank you to my very patient parents who fielded many an anxious phone call about this project or the life circumstances around it, and for all the great conversations around the fireplace or over pancakes that kept me sane. I also must recognize the efforts of my dear friends Graeson, Andrew, Joe and Ryan who have let me talk their ears off about central Oregon water politics well past the point it was appropriate in a conversation, and always offered their own perspectives to sharpen my ideas, keep me grounded and at peace.

Lastly, I need to recognize my fellow students in Dr. Cantor's lab group who have been exceptionally supportive throughout this project and offered great feedback every step of the way. It has been a privilege to work within this lab group. I am certain there is only great work to come from them all and I cannot wait to see where it takes them. 


\section{Table of Contents}

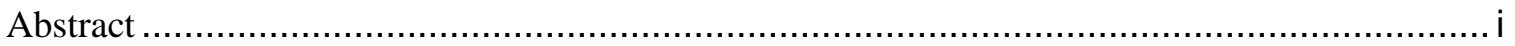

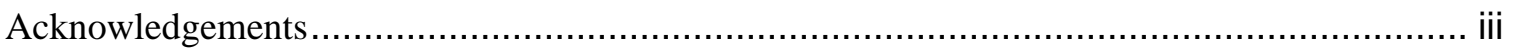

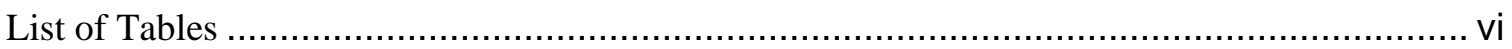

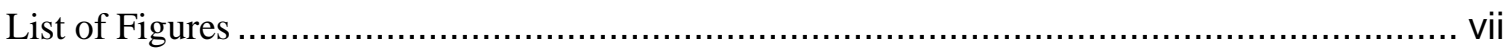

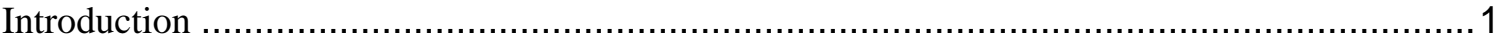

Collaborative Governance Stakeholder Theories and Sense of Place .................................... 4

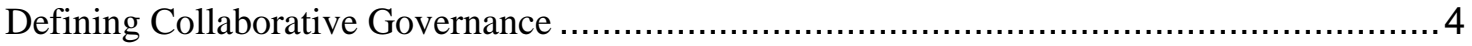

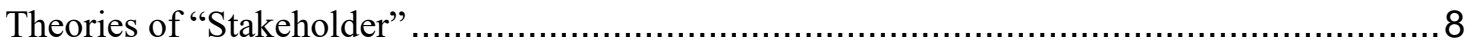

Stakeholder Consciousness, Sense of Place and Place Meanings .....................................10

The Deschutes Basin Habitat Conservation Plan ............................................................... 14

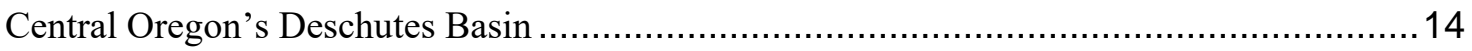

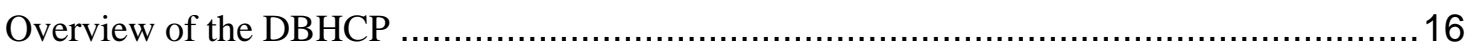

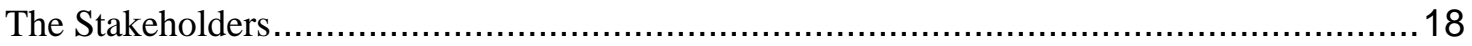

The Deschutes Basin Board of Controls .................................................................. 18

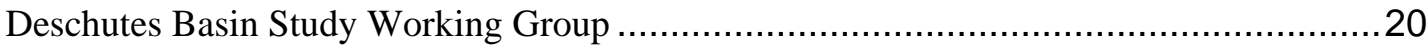

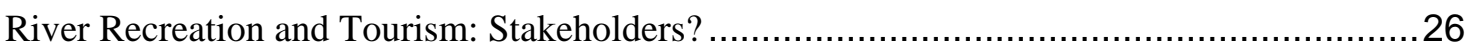

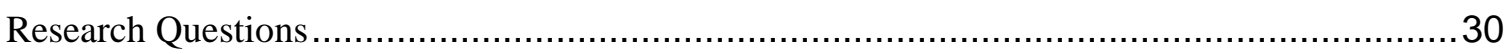

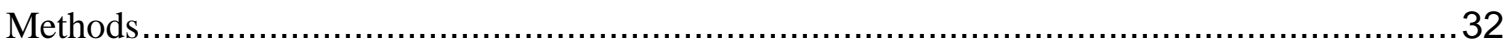

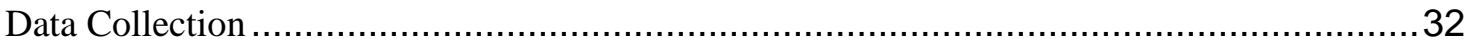

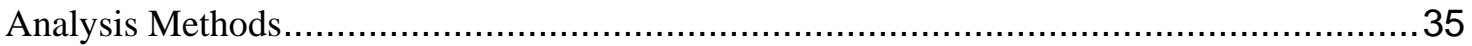

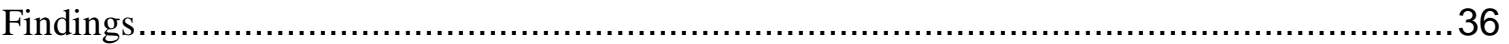

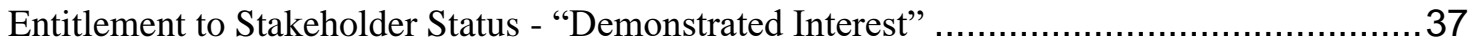

Stakeholder Status through Participation- Putting on the "Stakeholder Suit" ......................41

Senses of Place \& Stakeholder Formation................................................................ 45

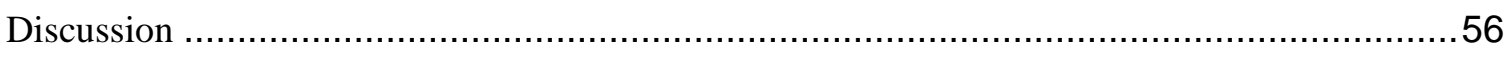

The "Interest-Action" Process of Stakeholder Formation ...........................................56

Reconciling the Interest-Action Model with Existing Liteterature .................................60

The River Recreation Community, Stakeholder Status \& Collaboration.............................65

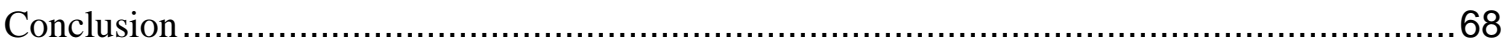

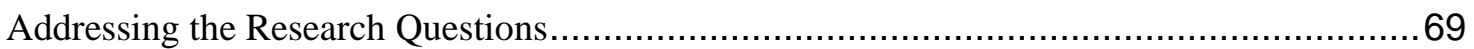




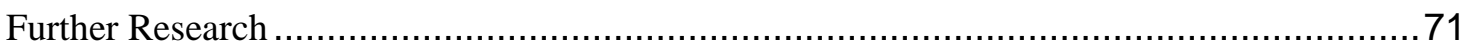

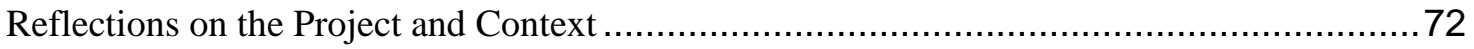

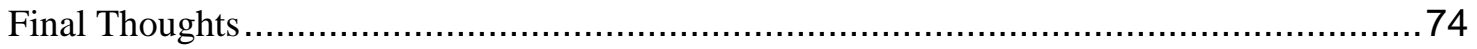

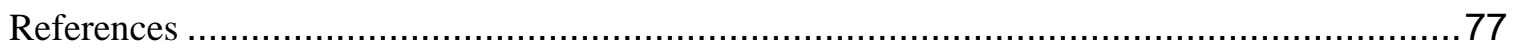

Appendix A: Table of Acronyms \& Initialisms ................................................................. 83

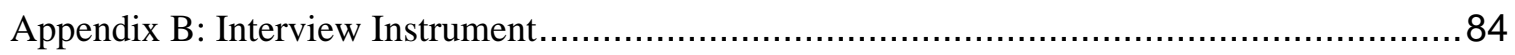

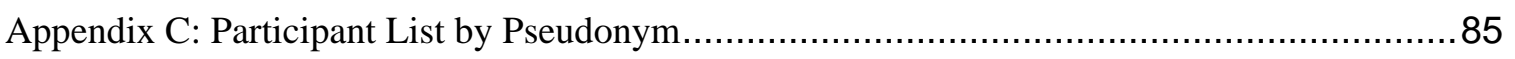

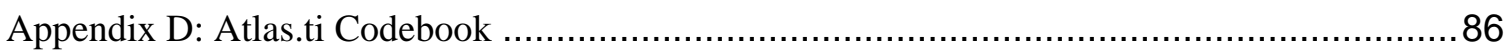




\section{List of Tables}

Table 1. Interview Participants by Primary Interest Group ............................................ 33 


\section{List of Figures}

Figure 1 Map of the Deschutes Basin \& the Deschutes Basin Board of Control Irrigation Districts 16

Figure 2. Deschutes Basin Habitat Conservation Plan Collaboration Structure .......................21

Figure 3 Interest-Action Process of Stakeholder Formation through Collaboration ..................57 


\section{Introduction}

In 2019, the Deschutes Basin Board of Control (DBBC) submitted to the US Fish and Wildlife Service their Deschutes Basin Habitat Conservation Plan (hereafter the Habitat Conservation Plan). The proposed habitat conservation plan seeks to increase the annual flows of the Deschutes River in order to protect the habitat of the Oregon Spotted Frog, Bull Trout and several migratory salmon species in the Deschutes Basin as mandated under the federal Endangered Species Act. In drafting this plan, the DBBC sought community stakeholder input in its design through a collaborative governance process. A working group was assembled representing the interests of various policymaking bodies and community groups, all understood to have some interest in the basin's water management practices. The plan's drafters intone multiple times the importance of the Deschutes River as the basis for "most of the economic and recreational activities" in Central Oregon. Through their bringing together a range of community stakeholders, those drafting the Habitat Conservation Plan aimed to make their policy craft representative of that diverse economic reality. Despite the importance of recreation, the river recreation community appears to have been mostly absent from the kinds of discussions the HCP describes. Overall, the outdoor recreation and amenity tourism constitute a rapidly growing portion of the Central Oregon economy, represented heavily in both tourism economic reports and marketing materials. If the river recreation community does represent an important stakeholder interest in the basin, and their industry stands to be impacted by the 
mechanisms of the Habitat Conservation Plan, the question arises as to why this group was not included in the collaborative governance process.

The purpose of this research is to investigate the manner by which stakeholders are constituted in the Deschutes Basin and to explore the ways that the "where" of collaborative governance is a factor. This work contributes to the scholarship on stakeholder theories and collaborative natural resource governance by illustrating the processes by which collaboration, while requiring stakeholders, itself can create them. To this scholarship I contribute a model of stakeholder formation through collaboration that accounts for the pattern of stakeholder formation I observed in the Deschutes Basin that accounts for the important role that the Basin, as a place, plays in that process. With this incorporation of place into the literature of stakeholder theories, I make the case that the critical examination of collaborative governance processes is a task well suited to the fields of human geography and political ecology, as the governing of natural resources the places from which those resources are drawn are not separable things.

Through a series of interviews with Deschutes Basin community members involved with collaborative water governance, the Habitat Conservation Plan and the various facets of the region's river recreation industry, what emerged was a model of stakeholder formation that seemed to differ in meaningful ways from the manner by which the process is described in prior research. In the context of the Basin's many collaborative water governance processes, stakeholder formation emerged as a twostep process: interest groups had to first demonstrate some property interest in the 
Basin's management and then follow that assertion up with participation in the collaborative process. This Interest-Action model of stakeholder formation, while paralleling much of the research done in this field, aims to account for the importance of place and place-meanings in the construction of stakeholders.

I begin this proposal by situating this research in the literature of collaborative governance, stakeholder theories, and the application of place-based approaches to managing social-ecological systems. I then explore the case of the Deschutes Basin Habitat Conservation Plan, diagramming the changes proposed to the Deschutes River it describes, the stakeholders represented in the plan, and its lack of conformity with a uniform stakeholder theory. I then discuss the tourism and recreation industry, its importance in the Deschutes Basin and the impacts it faces resulting from the Habitat Conservation Plan. Bringing this case study into conversation with the literature, I then propose three research questions to explore that emerge from the stakeholder situation in the basin's apparent incongruity with the patterns of stakeholder formation theorized in the literature. These questions are then followed up by a description of my data collection and analysis methods, the findings from those methods and a discussion of their implications and importance. The paper then concludes with some broader thoughts on the nature of collaborative governance as a process and the roles that geographers may play in their future development. 


\section{Collaborative Governance Stakeholder Theories and Sense of Place}

This research is broadly situated within political ecology scholarship which seeks to explore the co-constitutive relationship between human policymaking and environmental and ecological systems (Robbins 2011). I draw upon scholarship on collaborative natural resource governance to explore the documented successes and challenges of collaborative governance processes, and to illustrate the importance of such processes to the state of Oregon where this research is focused. I then draw upon literature discussing stakeholder theories, borrowing ideas from work in natural resources, program management and rural studies to illustrate the breadth of theories on how stakeholder formation takes place. Lastly, I bring together an emerging literature in social-ecological systems to highlight the importance of competing senses of place and place meanings to understanding individuals and community group's complex relationships with the political structures that govern the places they live and utilize.

\section{Defining Collaborative Governance}

Collaborative governance describes the policy development structure by which governing bodies work alongside community stakeholders in a landscape to craft policy and make decisions through consensus (Singleton 2002). Ansell and Gash (2007) expand on this further, describing collaborative governance as needing to be initiated by public entities, that community participants are truly engaged in the process of creating policy rather than just consulted, and that the focus of such efforts 
should be on matters of public interest. Broadly, the collaborative process is understood to generate novel and innovative solutions to resource management by incorporating local and region-specific approaches into more traditional top-down policymaking (Satein 2017, Levesque et al. 2017). In the United States, this model often serves as the interface by which federal agencies have addressed the need for community input on environmentally important policy changes mandated under the National Environmental Policy Act (NEPA) and Endangered Species Act (ESA). The NEPA Collaboration Handbook describes the collaboration process as important for improving the quality of decision-making and important for the development of public trust and confidence in government environmental decisions (NEPA 2007).

While heralded as a process broadly inclusive of a community's total interest, a literature exists highlighting the nuance and difficulty present in collaborative governance processes, and the ways by which the stakeholder needs may be only selectively met in a collaborative process. Davis et al. (2018) have documented community collaborators in Oregon forest management are often those with direct financial "buy in" to the landscape being managed collaboratively. The community groups present in the forest management negotiations, while often representing environmental concerns may be composed primarily of those invested in property and industry that would be directly impacted by changes in forest management practice (2018). The authors also noted that the community collaborators seldom held directly opposing views on management practice to the governing bodies, differing in opinion primarily on best practices for achieving management goals (2018). Further, the goals, 
priorities and markers codified by participants, while appearing empirical, may be derived from the external interests of those participating in the effort rather than serving a broader constituency (Fernandez 2014). This would suggest that the interests represented in collaborative governance schemes may be unrepresentative of the community's interest the process itself is designed to serve.

Research has also highlighted the important role of trust and clear communication in the collaboration process and the ways a breakdown of either can alter policy outcomes. Differing expectations between community groups and lawmakers as to the degree of community group autonomy in policy making and the division of responsibilities can create tension in the collaboration process, reducing the prevalence of community favorable outcomes (Davies and White 2012). The degree of trust held between community groups and governing bodies plays a critical role in shaping the collaborative process (Levesque et al. 2017, Davenport et al. 2017). Stakeholders may be reluctant to voice real concerns, opting to not "push" issues in maintenance of cordiality between interest groups and policy makers (Davis et al. 2017, Davenport et al. 2007). Davenport et al. (2007) note that the formalization of community input through a collaborative governance structure may leave local communities not represented or underrepresented in the process feeling marginalized and create opposition to proposed policy changes in the broader community. The formalization of participatory processes may also serve to erode trust between participants in a collaborative effort if non-governmental participants perceive 
imbalances of power highlighted through participation structures (Innes and Booher 2004).

Strong examples of collaborative natural resource governance can be found in the state of Oregon. Many of the state's watersheds and public forests are governed by collaborative efforts between policymakers and regional interest groups (Dakins, Long, and Hart 2005, Davenport et al. 2007, Davis et al 2018, Paretchan 2010). In undertakings like the Habitat Conservation Plan, large working groups are frequently assembled to advise policymakers in such environmental decision-making processes. Like other collaborative efforts in Oregon though, those taken in the Deschutes Basin have had their challenges (Davis et al 2018, Satein 2017) In the Deschutes Basin, community groups feeling dissatisfied with the pace of action and communication in the negotiation of the Habitat Conservation Plan have used litigation under the citizens' provision of the ESA to drive new water management policy forward (Satein 2017).

The question then arises as to the difference between groups with important interests in a landscape, and "stakeholders" as official parties involved in collaborative governance practices. If stakeholders are those with similar policy aims to the governing bodies with which they collaborate, interest groups with opposing stances may be left out of the collaborative process. Interest groups who perceive their needs unmet by collaborative governance may possess the ability to legally challenge new policy agendas. However, the legal structures may not exist for all those feeling disproportionately impacted by policy changes to sue. In the case of the Habitat 
Conservation Plan, stakeholders concerned that the collaborative process was moving too slowly to adequately protect Oregon Spotted Frog habitat in the basin possessed actionable legal standing under the ESA (Satein 2017). The legislation creates specific avenues of recourse for citizen groups to pursue claims against policy makers and industry on behalf of endangered species, but not all stakeholder interests are protected specifically in the law. If a stakeholder group is not a party to collaborative governance policy, and they lack legal standing with which to make their concerns heard, the question remains as to how these stakeholders may communicate their needs and avoid disproportionate impacts to their interests from new environmental policy designed to be inclusive of all stakeholder needs.

\section{Theories of "Stakeholder"}

The concept of "stakeholders" in resource governance and management literature is prolific. There is, however, debate as to the definition and appropriate scope of the term. Grimble and Wellard (1997) define stakeholders as “... any group of people, organized or unorganized, who share a common interest or stake in a particular issue or system ..." (in Billgren and Holmén 2008). Buanes et al. (2004) offer a narrower definition of stakeholder, borrowing a typology defined by Mitchell, Agle, and Wood (1997) by which stakeholders can be classified based on their possession of power, legitimacy, and urgency. Buanes et al (2004) propose that through scoring stakeholders based on these key attributes, a hierarchy of stakeholder importance can be developed typifying "definitive" stakeholders, whose interests will 
factor into natural resource governance decisions, "expectant" stakeholders with interests who expect to be considered but may not be, and "latent" stakeholders who may become definitive stakeholders but are not presently. In this model, stakeholder status is determined by the policymaking body based on observed needs (Buanes et al, 2004), however all stakeholders in a landscape may possess unmatched abilities and resources by which to make visible and obfuscate different sets of priorities (May, 2015). May further posits that stakeholders are legitimized through this competition for visibility and the furtherance of "unchallenged, taken for-granted predispositions concerning current trajectories of economic development among the broader public." (2015). All three scholars agree that the property of "stakeholder" is something dialectically produced by actors in a landscape or system who all have some interest in its management while offering different perspectives on the origins of the power that legitimates those interests.

What emerges is a validation of Billgren and Holmén's (2008) suggestion that a unified theory of "stakeholder" may not exist. Rather, being a stakeholder may be more easily understood intrinsically by individuals in a landscape (2008). The authors describe this understanding as a "cultural" theory of stakeholder formation (2008). In much the same way that humanistic geographers such as Tuan (1990), Relph (1976) describe "place" as being a dialectic product of individuals cultural inputs interacting with their sensory perception of a landscape, Billgren and Holmén argue that the creation of a stakeholder is bound to the cultural landscape of the stakeholder (2008). By integrating a recognition that an individual's understanding of their own 
stakeholder status may be shaped by their own cultural background, the author's account for the possibility of a variety of senses of stakeholder status not explored in other theories. Pederson (2006) describes this phenomenon as a "stakeholder consciousness", whereby the awareness of one's position and circumstances are a constituent piece of their own stakeholder status. By placing the designation of stakeholder status within the worldview of potential stakeholders themselves, this framing accounts for a variety of understandings of stakeholder within the same landscape. Rather than being an observable attribute of an interest group, a stakeholder may be something one feels they are.

\section{Stakeholder Consciousness, Sense of Place and Place Meanings}

Much of the literature on stakeholder formation focuses on a top down process by which stakeholder status is constructed or delegated, however there exists a body of literature exploring the ways that individuals construct their own understandings of policy and the environment through their own experience and perception. In their work The Common Place of Law, Ewick \& Silbey (1998) outline their framework of "legal consciousness". In this framework, law, policy and the different spaces they create instill in the public a variety of understandings of their personal positionality in relationship to the law (1998). Through the examination of peoples experience created by, and within policy structures, Sibley argues that research conducted on people's perception of their legal positionality can function as a tool to examine hegemonic power structures through their different experiences of the law (Silbey 2005). This scholarship is paralleled in geography sense of place scholarship in Massey's 
exploration of power geometries (1994). Pedermen (2006) brings this thinking to bear on stakeholder relationships, elaborating that "stakeholder consciousness" is shaped by a participants perception of their collaborative environment, their own personal values, and their ability to engage and implement collaboratively determined policy outcomes. Veldhuizen notes that a variable stakeholder consciousness between participants may yield different levels of stakeholder engagement (Veldhuizen, Bolk, V, and Dentoni, D 2012).

There has also emerged a literature exploring the relationship between groups' different senses of place and their proclivity to participate in policy making. This literature seeks to expand upon the work of Tuan (1990) who explored the ways by which "place" is constructed at the individual level as a dialectically produced phenomenon between the environment and the cultural inputs an individual is bringing to bear in their perceiving that environment. In this way, the discourse of language used to describe a place may be central in the way an individual constructs it (Stokowski 2002). Different understandings of a place's history and mythology can create variability in different group's perceptions of a place (DeLyser 2001; Johnstone 1990). However, the ability to craft the narratives or experiences of a place may be unevenly distributed among all those participating within it. Rather, there may be external, societal factors mediating people's ability to experience and define those places. Different senses of place held by different groups with different amounts of power may compete on "uneven footing" when defining a place (Stokowski 2002). 
In the field of social-ecological systems research, authors have begun to explore the ways that these unevenly matches senses of place compete in the realm of environmental governance. Stedman (2016) acknowledges that social-ecological systems themselves are subjectively understood and acted upon by the various actors in a landscape based on their own worldviews. The author draws attention to the concept of "place meanings"; distinct from an individual's "place attachment", place meanings describe a party's descriptive understanding of what a place is supposed to be, working to create normative narratives of a place's nature. These place meanings can be abstracted beyond a singular location and become attached to kinds of places, that when situated in broader political discourses can become symbolic sites of political action (Ingalls et al 2019). When one group perceives a place as being utilized in a manner antithetical to their own views of a place's purpose, political action may be undertaken to protect what a group perceives to be that place's essential purpose (Ingalls et al 2019). Enqvist et al (2019) examine this relationship between place meanings and governance through the lens of environmental stewardship. Through their examination of outdoor recreators on various water bodies around New York City, they documented that landscape uses rooted in kinds of places rather than specific locations appear to mediate the degree to which recreators feel compelled to engage in environmental stewardship; when the act of recreating became the focus rather than the place in which an individual recrated, the reduced place attachment correlated with reduced desire to participate in the governance of that specific river (Enqvist et al 2019). 
In the stakeholder theories discussed in the previous section, stakeholder status was discussed as something understood about an interest group by the larger governance structure in which they were situated. The literature discussed above suggests that one's perception of place, understanding of place meanings and their positionality in relation to the policymaking process have considerable bearing on their ability and willingness to participate in governance. Broadly, one's stakeholder status may be something that is both externally constructed through power structures, while also intrinsically understood based on one's own perceptions, experiences and cultural inputs. This tandem construction of stakeholder status may then create circumstances in which an individual understands themselves to be a stakeholder in an environmental system, but not recognized as such by the polity of other interest groups in the basin. Conversely, a group may not perceive themselves to be stakeholders in a system while many other groups would ascribe such status to them. In collaborative governance models, this tandem construction of stakeholder status may lead to some excluded interests taking issue with their exclusion if they perceive themselves to be stakeholders but the border interest base of the region in question does not recognize them as such. 


\section{The Deschutes Basin Habitat Conservation Plan}

\section{Central Oregon's Deschutes Basin}

The Deschutes River Basin is a large, multi-river watershed in north-central Oregon abutting the eastern side of the state's portion of the Cascades mountain range. Draining into the Columbia River, much of the basin's peak flows are derived from the Basin's northern reaches, where the region's porous volcanic geology supports a robust groundwater system (O’Connor et al, 2013). As a result, the mean hydrograph of the Deschutes River maintains much of its stability from season to season (O’Connor et al, 2013). The stability of these flows has facilitated the development of a large river recreation sector in the Basin, who are able to take advantage of high river stages through the summer months.

While spanning 6 counties, the majority of the Basin's population is focused around the city of Bend, OR in Deschutes County with an estimated population of 100,421 residents as of 2019 (US Census Bureau Quick Facts: Bend city, Oregon, n.d.). By comparison, the rest of the Basin is substantially more rural, with the next largest population center, Redmond, OR having an estimated population of only 32,421 (US Census Bureau Quick Facts: Redmond city, Oregon, n.d.). In order to facilitate the distribution of the Basin's water resource for use in agriculture, the area's residents have established 8 irrigation districts for the purposes of constructing and administrating the necessary infrastructure to distribute the Basin's apportioned water to the region's water rights holders. The administrative boundaries of each of these districts and the region's population centers are presented in the map below (Figure 1). 
These 8 irrigation districts, in 2002, came together establishing the Deschutes Basin Board of Controls as an overarching administrative unit to facilitate collaboration more easily between districts on water conservation and service improvement initiatives (DBBC 2019).

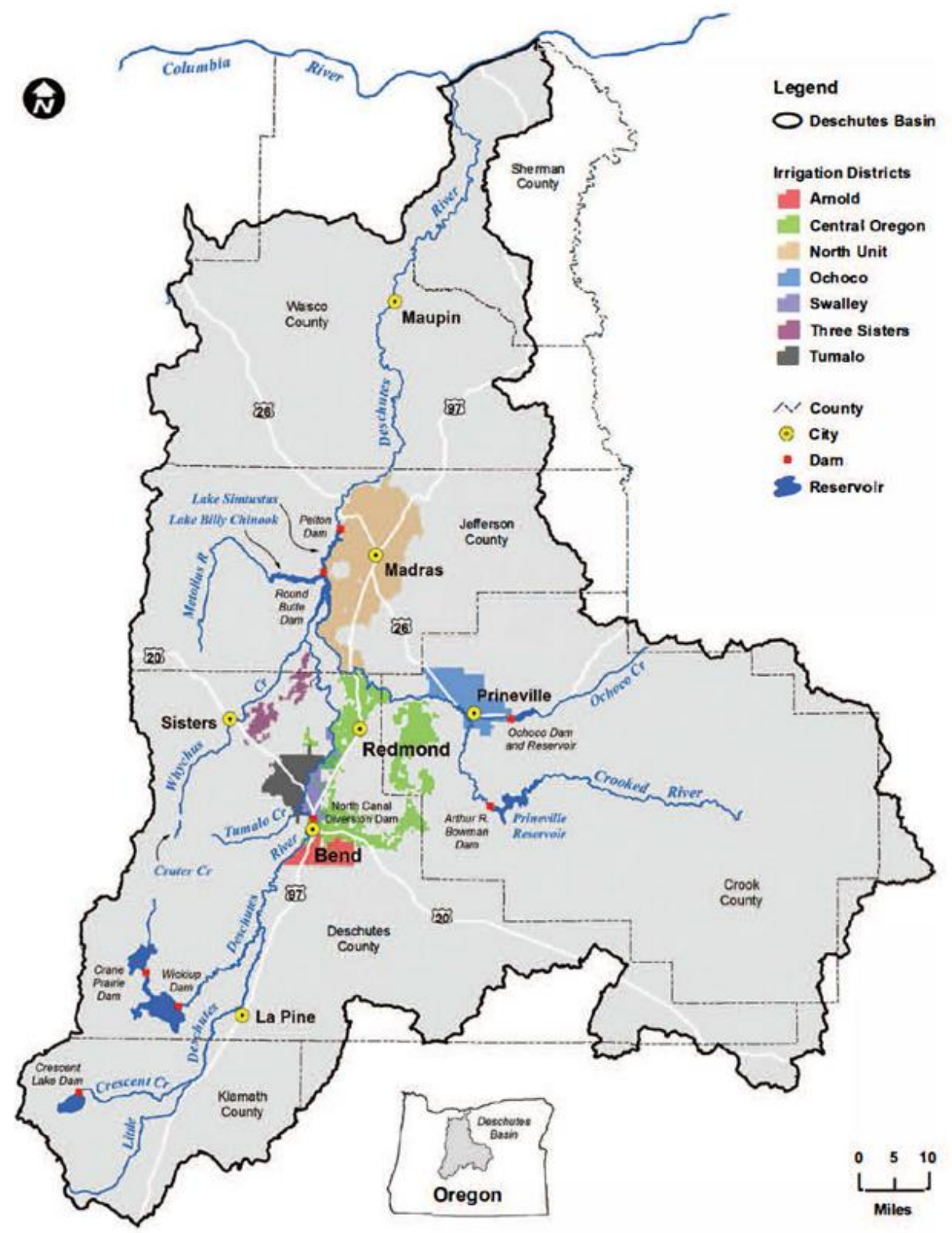


Figure 1 Map of the Deschutes Basin \& the Deschutes Basin Board of Control Irrigation Districts

(DBBC 2019)

\section{Overview of the DBHCP}

In 2019, the DBBC submitted the Deschutes Basin Habitat Conservation Plan to the US Fish and Wildlife Service and National Marine Fisheries Service. In 2014 several central Oregon species were placed on the Endangered Species list including the Oregon Spotted Frog, Bull Trout, and multiple species of migratory salmon (WAFWO - Oregon Spotted Frog n.d.). This designation has required large scale remediation of river management practices in the Deschutes Basin in order to protect the habitat of these species and align the DBBC's management practice with the new federal mandates for river flow stages and instream passability for migratory fish (DBBC 2019). The plan outlines the current state of species habitat in the basin and outlines the methods to be undertaken by the signatory irrigation districts to minimize the incidental taking of these endangered species while maintaining the delivery of apportioned Deschutes River water to their constituent rights holders.

The changes to the river proposed by the Habitat Conservation Plan seek to better preserve and protect endangered species habitat in the basin through the increasing of annual instream flows of the Deschutes and the decreasing of tributary reservoir storage capacities. The Crane Prairie Reservoir proposed to reduce the variability of its surface level from $9 \mathrm{ft}$ annually to a maximum of $2.5 \mathrm{ft}$ and reduce 
the annual storage and release volumes from 50,000 acre-feet to 10,000 acre feet (DBBC 2019). The Wickiup Reservoir is to forgo storage on a gradually increasing series of volumes, forgoing $100 \mathrm{cf}$ for years one through five of the plan, $200 \mathrm{cf}$ for years six through ten of the plan, and further forgoing an additional $100 \mathrm{cf}$ every five years until the plan is reevaluated (2019). The Wickiup Reservoir will also be responsible for achieving and maintaining river flows above $600 \mathrm{cf}$ by April annually to support habitat for Spotted Frog breeding (2019). Crescent Lake Reservoir will increase managed flows from $6 \mathrm{cf}$ to $20 \mathrm{cf}$ from October through June, and maintain a minimum flow of 50cf through the summer months (2019).

The separate irrigation districts in concert will be responsible for maintaining flows above 250cf on the Deschutes River below Bend, Oregon to facilitate passage of migratory fish (2019). These measures will serve to allocate more water for instream uses prior to the irrigation districts apportionment processes. By doing so, the measures also codify an increase in the future stage of the Deschutes River overall.

In drafting the Habitat Conservation Plan, policymakers in the Deschutes Basin Board of Controls brought together a group of regional stakeholders in order to bring community voices into the plan creation process. These efforts at collaboration took the form of the Deschutes Basin Study. This $\$ 1.5$ million dollar project brought together a 40 member stakeholder group of community members, agricultural interests, environmental economists and others to develop recommendations on implementable river management solutions that would equitably facilitate the 
returning of the Deschutes River to a state more conducive to wildlife habitat while maintaining the river's ability to deliver already apportioned agricultural water. The study examined many methods of improving water efficiency, exploring the efficacy of projects like irrigation canal lining, canal piping and water banking, but went only so far as to provide potential guidance to water managers. Ultimately, the recommendations of the study were non-binding for the irrigation districts applying for the incidental take permits through the HCP process. As a final document, the Habitat Conservation Plan frequently evokes the language of collaboration and the convening of stakeholders; the assembly of the group participating in the Deschutes Basin Study Work Group was the foremost manner these collaborative efforts were undertaken. The final Habitat Conservation Plan document itself was drafted in total by the DBBC and the City of Prineville, the two parties seeking the incidental take permits for taking endangered species and representing the majority of the agricultural interest in Deschutes River management.

\section{The Stakeholders}

To diagram the structure of this collaborative process, it is important to understand the interests and authorities held by the parties to the negotiations. In the following sections I briefly describe the structure of the collaborative effort and the members of the Deschutes Basin Study Working Group assembled to develop the Plan.

The Deschutes Basin Board of Controls 
The predominant voice in Deschutes Basin policy making is the Deschutes Basin Board of Controls (DBBC), a governing coalition of central Oregon's eight major irrigation districts (Paretchan 2010). Formed in 2002, this body's stated goals are to "coordinate and share their respective resources and management assets to conserve water, improve their services for farm and ranch families, and enhance river conditions for wildlife species and recreational opportunities." (About | Deschutes Basin Board of Control). The primary work of the DBBC in the last decade has been to improve irrigation system efficiency and to develop new strategies to conserve water. Efforts undertaken to repair and pipe inefficient irrigation canals, the mitigation of irrigation diversion structures impassable to native fish species and the continued management of the region's hydroelectric power systems (About | Deschutes Basin Board of Control). Many of the irrigation districts composing the DBBC were established in the early 20th century, and presently hold many of the Deschutes Basin's senior water rights (Paretchan 2010, DBBC.com n.d). The group served as the main body directing the creation of the Deschutes Basin Habitat Conservation Plan and will be the party responsible for its administration.

The group's largest signatory, the Central Oregon Irrigation District (COID) is responsible for managing the region's main hydroelectric power system, the Siphon Power Project, and co-manages the Crane Prairie Reservoir in the east cascades (About Us $\mid$ Central Oregon Irrigation District n.d.). This 5.5-megawatt dam, in addition to providing much of the region's electric power, also serves to manage the Deschutes overall flows, allowing regulated control of the river's discharge 
throughout the year (About Us $\mid$ Central Oregon Irrigation District n.d.). The COID manages 700 total miles of irrigation canal, and is the primary provider of agricultural, industrial and municipal water to the region's main population centers in Bend and Redmond, Oregon.

Deschutes Basin Study Working Group

The DBHCP working group was composed of various administrative and community organizations representing various stakeholder interests in the Deschutes Basin. Per the language of the report, governmental agencies and organized nongovernmental agencies with an established interest in the Deschutes River were invited to participate in the collaborative process beginning in 2008 (DBBC 2019). The list of stakeholder participants, as presented in the Habitat Conservation Plan found below: 
2Figure 2. Deschutes Basin Habitat Conservation Plan Collaboration Structure

Deschutes Basin Habitat Conservation Plan Collaboration Structure

\section{Deschutes Basin Board of Control}

- Arnold Irrigation District

- Central Oregon Irrigation District

- Lone Pine Irrigation District

- North Unit Irrigation District
- Ochoco Irrigation District

- Swalley Irrigation District

- Three Sisters Irrigation District

- Tumalo Irrigation District<smiles>CC12[C]C(CC1)CC2</smiles>

Deschutes Basin Study Working Group Participants

Government Organizations

- USDI Bureau of Reclamation

- USDI Bureau of Land Management

- USDA Forest Service

- Confederated Tribes of Warm Springs

- Oregon Water Resources Department

- Oregon Department of Environmental Quality

- Crook County, Oregon
Watershed Councils

- Upper Deschutes Watershed Council

- Crooked River Watershed Council

NGO's

- Trout Unlimited

- WaterWatch Oregon

- Deschutes River Conservancy

- American Rivers

Utility Companies

- Portland General Electric

(DBBC, 2019) 
Eight of the working group participants represent the interests of governing bodies with stake in the Deschutes River. The federal government organizations present represent the interests of the agencies governing timber extraction (USFS), dam construction, irrigation management (BoR) and public lands administration (BLM). The Oregon Department of Environmental Quality (ODEQ) serves as the state agency responsible for "restoring, maintaining and enhancing the health of the quality of Oregon's air, land and water" (State of Oregon: Department of Environmental Quality - Home). The Oregon Water Resources Department (ORWD) serves as the holder and delegator of Oregon water rights; surface and groundwater in the state of Oregon all first belong to the state, where through the OWRD water rights are distributed according to prior appropriation (Pilz 2006). Also represented in the collaboration were the Confederated Tribes of Warm Springs who have indigenous fishing and irrigation collaboration interests in the basin (Manion 2017).

The NGO organizations in the working group represent a wide range of environmental concerns, each with their own specific policy focuses. The Deschutes River Conservancy, founded in 1996, states that their mission is to "restore streamflow and improve water quality in the Deschutes Basin" (Deschutes River Conservancy Reauthorization Act of 2005 :report (to accompany S. 166). 2005). Trout Unlimited is a national organization advocating on behalf of trout habitat conservation and sustainable fishing practices. The group also advocates strongly on behalf of dam restructuring and removal (Trout Unlimited- Home). WaterWatch Oregon purports to 
be "the only conservation organization devoted exclusively to restoring and protecting natural flows in Oregon rivers and streams" (WaterWatch Oregon- Home). Included in this group's goals are the protection of instream flows on behalf of fish, wildlife and "the people who depend on healthy rivers" (WaterWatch Oregon- Home). AmericanRivers presents themselves as a scientifically minded organization combining advocacy work with field work and research to protect American rivers from pollution and the impacts of energy development. Portland General Electric was also a party to the collaborative process, representing the interests of a portion of the region's electrical utility.

Two watershed councils also participated in this collaborative effort: the Upper Deschutes Watershed Council and the Crooked River Watershed Council. Organized under the Oregon Watershed Enhancement Board (OWEB), watershed councils in Oregon are themselves examples of collaborative natural resource governance. OR 514.910 states that voluntary watershed councils of community members may be established for the purposes of "protecting or enhancing" the quality of a given watershed. The statute further stipulates that the majority of seats in a watershed council are to be held by local residents representing a "balance of interested and affected persons within the watershed" (ORS 541.910 - Voluntary local watershed councils - 2017 Oregon Revised Statutes n.d.). The mission statements of both the Upper Deschutes and Crooked River watershed councils both emphasize habitat restoration, community outreach and waterway health monitoring (Crooked River Watershed Council n.d., Mission and History - Upper Deschutes Watershed Council 
n.d.). The Upper Deschutes Watershed Council website does mention river recreation activities as having importance in the basin's management agenda, however they do not elaborate on this importance or what activities they may engage in to support such industry through their restoration efforts. The Crooked River Watershed Council's mission statement includes mention of the watershed council serving as a mediation body between stakeholders in the watershed, and that stakeholder's socio-economic interests are a consideration in their management strategy (Crooked River Watershed Council n.d.). While both groups are organized under the same legislation, it is also important to note that size difference between these two organizations. The Upper Deschutes Watershed Council is composed of a 15 person board of directors and 6 full time staff. The Crooked River Watershed Council is composed of three members in total.

Broadly, the stakeholders in the negotiation are those expected to be present per the literature on collaborative governance efforts in Oregon. Policymakers and community groups with similar goals were able to come together to draft new policy that appears to work in the interests of all involved to varying degrees. From examining the various interests, goals and mission statements of the participating organizations, what remains unclear is what factors warranted an organization's invitation to participate as no singular theory of stakeholder seems to explain this group of participants while excluding others. The Habitat Conservation Plan document itself recognizes that very few residents of the basin will be unaffected by changes in river management practice, including everyone, organized or not as a 
community stakeholder as Grimble and Wellard (1997) would describe, however the interests represented are significantly more narrow than all of those held by all residents of the basin. The typology put forward by Mitchell, Agle, and Wood (1997) accounts for the presence of policy making bodies with jurisdictional power, and utility companies reliant on water resources to supply the region with electricity, but does not quantify the levers of power, urgency or legitimacy by which specific NGO's gained stakeholder status over others, or how legitimations may be contextually dependent. May's theory that legitimation is achieved through competition for visibility would seem to reconcile this gap; some organizations may market themselves more than others. In the context of the Habitat Conservation Plan however, visibility as a path to stakeholder legitimation would suggest that a stakeholder group like the river recreation community, figuring prominently in regional branding, would be expected to participate in the collaborative governance process. What this seems to suggest is the presence of other regional factors constituting the status of "stakeholder" as recognized by policy makers for the purposes of participating in collaborative governance.

The DBBC through the Habitat Conservation Plan, have decided that the Deschutes River is going to flow higher through winter months in order to protect habitat for endangered species. By arriving at this decision through a collaborative governance process, policymakers have presented this outcome as one of consensus held by the legitimized "stakeholders" in the region. The question then arises as to what factors constituted an interest group being represented in, and thus legitimized 
by, this collaborative governance process, and who may be disproportionately impacted by being left out of consideration. The Basin's river recreation community appears as an example of a stakeholder group unrepresented in this collaborative process, who the literature would suggest should have been considered a "stakeholder". The river recreation industry may incur disproportionate impacts by virtue of this lack of representation. In the following section I explore the stakeholder status of the river recreation community, and risks posed to the community by reductions in normally high summer flows in the Deschutes River.

\section{River Recreation and Tourism: Stakeholders?}

People have been traveling to Deschutes County in pursuit of the landscape's assets for more than one hundred years. For most of its history Bend, Oregon's landscape served as a production hub for timber and cattle. The area's vast stands of Ponderosa Pine and large swaths of prime grazing land had been eyed for logging and cattle raising by development companies seeking to develop in the west along the ever expanding trans-continental railroad networks as early as 1887 (Davidson 2005). While its position on the Oregon Trunk Link railroad connection poised the region to serve an industrial purpose, early recognition of the landscape's idyllic qualities was also noted on a national scale; the National Forest Service issued its first guides for recreation in the Deschutes National Forest as early as 1911(2005). By the late 1930's the Deschutes National Forest had become one of the West's most popular outdoor recreation destinations (2005). 
Today, tourism is a critical component of the central Oregon economy, accounting for approximately $15 \%$ of the region's economic activity (Oregon Travel Impacts: 1991 - 2018, Dean Runyan Associates 2019). According to the Oregon Travel Impacts Report (OTIR), overnight and day tourists spent approximately $\$ 670$ million dollars in Deschutes County in 2018. This number is part of an upward trend in tourism spending. In 2018, travel and tourism accounted for $36.4 \%$ of the region's tax revenue; in 2010 the percentage was 18.9 (2019). In this same timeframe, day traveler spending in the region has grown from $\$ 70.2$ million to $\$ 104.4$ million (2019). In total, the report states that the tourism and amenities sector is directly responsible for 1260 jobs in the region as of 2018. It is also noted that these are the jobs tied directly to the tourism and recreation industries; these numbers do not account for those jobs supported by tourist dollars and those created to support a growing exurban population like construction and healthcare (Tourism | City of Bend n.d.).

The Deschutes River features as a prominent character all of the marketing materials for the region's tourism industry. Featured prominently on Visit-Bend.org's recommended activities page are recommendations for kayaking, rafting, paddle boarding and fishing excursions Bend Area Visitor Survey Summer 2017 Final Results, RRC Associates 2017. According to Whitewater Guidebook, the Deschutes is home to some of the most popular stretches of whitewater in the state of Oregon, requiring those seeking guided expeditions to make reservations months in advance (Deschutes River I Whitewaterguidebook.com 2014). The status of these prime 
recreation opportunities and the state of the Deschutes River itself are linked; changes in the river's flow will mean changes to the river's landscape on which these industries so important to the regional identity depend upon. The importance of this linkage between recreation opportunities on the Deschutes and the regional economy would appear to be the kind of quantifiable interest that would raise the river recreation community to a "stakeholder" status similar to those of the Habitat Conservation Plan Working Group Members.

The basin management measures outlined in the Habitat Conservation Plan will reduce storage volume of the Basin's reservoirs through the winter, increasing flow volumes through the colder months (DBBC, 2019). As a consequence, the normally high summer flows experienced in the basin generated to support irrigation agriculture will be diminished. Oregon rivers running low begins to raise concern for recreation users and their surrounding communities as the broader perceived quality of recreation opportunity diminishes with the river stage (Whittaker and Shelby 2002; Rood et al. 2006) and hazards once submerged become obstacles to navigate. These concerns already exist in mountain tourism hubs as a product of climate change (Scott 2003) changes in river management practices notwithstanding. Through the implementation of the Habitat Conservation Plan, these concerns over summer river stage will only be augmented, further increasing the impact of the plan's implementation felt by the river recreation community.

Both the increase in risk and changes in marketable landscape would seem to constitute an "established interest" held by the industry in the river's management. 
The share of the regional economy represented by these industries appear to place them as important stakeholder voices in the Central Oregon community. Regardless of these apparent linkages, the interests of the recreation community appear largely underrepresented in the plan. In total the words "recreation" or "recreational" only appear in the plan a total of 24 times in the entire 871-page report. The river recreation community appears to meet the criteria the literature suggests constituting stakeholder status, however, the clear representation of the recreational community's voices in the drafting of the Habitat Conservation Plan, is unapparent in this collaborative governance process. It is from this observation that I have constructed the research questions to be pursued in this investigation. 


\section{Research Questions}

Through this research, I am seeking to investigate what factors are constituent of stakeholder status in the Deschutes Basin. The river recreation community's lack of inclusion in the Habitat Conservation Plan and its working group seems to cut against my understanding of what a community stakeholder actually is in the collaborative process. If tourism and recreation interests are demonstrably important to the region's economy, and the impacts of the plan upon those interests will be severe, these industries appear to be "stakeholders" of some kind in the management of the Deschutes Basin, but not in a way that could be recognized or legitimized by policymakers through collaborative governance participation. If the process is designed to generate local knowledge for use in top-down policy decisions, the selection of which "local" knowledge to draw from may have disproportionate impacts on the groups whose voices are not heard. In bringing together the working group that was assembled, the DBBC held considerable power in legitimizing which interests are and are not representative of the community being served. The stakeholder interests legitimized through the Habitat Conservation Plan collaboration do not conform to a uniform stakeholder theory, with its divergence from those theories appearing to hinge on the specific geographic and social realities of the Basin. However, what those confounding factors are, and the mechanisms by which they were determinative are not clearly understood. From this, three research questions emerge: 
- How are "stakeholders" in Deschutes Basin management determined and legitimized in collaborative resource governance processes?

- What is the River Recreation community's relationship to the collaborative water governance processes in the Deschutes Basin?

- What role does sense of place play in the construction of stakeholder status in the Deschutes Basin/Central Oregon?

These are the three questions I attempted to answer in this research. In the following section I discuss the methods I employed to do so, and the analysis and findings resultant from those efforts. 


\section{Methods}

\section{Data Collection}

In geographic research, interviews are used to deepen understandings of interpretations, experiences and perceived spatialities of social interactions (Dowling, Lloyd, and Suchet-Pearson 2016). For this investigation, I conducted 15 semistructured interviews with policymakers, river recreation industry professionals, NGO representatives and other participants in the collaborative efforts surrounding the Habitat Conservation Plan. While the structure was often fluid, our conversations broke down into three subject areas: their experiences in collaborative governance efforts in the basin and within the Habitat Conservation Plan, understandings of stakeholder relationships and power, and the role that the river recreation industry plays in the Basin's social and political landscape. In addition to these main topics, I also had participants situate themselves both professionally and personally in the Deschutes Basin. Most participants interviewed, by nature of their work, had many personal experiences as outdoor recreators that were frequently brought to bear on their professional lives. Having participants situate themselves allowed me to more deeply explore the complicated role that different senses of place in shaping the creation of stakeholders and the broader collaborative governance experience in the Deschutes Basin.

My initial list of contacts was provided by a community partner within the Coalition for the Deschutes, an environmental activist organization working on river health issues in the Deschutes Basin. This list was composed of community 
representatives from the river recreation industries, irrigation district managers, NGO representatives and local policymakers who had all volunteered to participate in a community round table discussion in the spring of 2020 on the issues posed to river recreation industries by the measures proposed in the Habitat Conservation Plan. From this initial list, I utilized a snowball sampling method, asking for participants to refer me to those whom they thought may have important perspectives on this research. From my initial list of 30 contacts, 10 interviews were conducted representing each of the four identified collaboration participant types (policymakers, recreation industry professionals, NGO representatives, and agriculture/irrigation professionals). 5 additional interviews were conducted based on referrals from the initial 10. The interview participants sorted into 5 primary interest groups; the number of each in each category is tabulated below:

Table 1. Interview Participants by Primary Interest Group

\begin{tabular}{|l|l|}
\hline \multicolumn{1}{|c|}{ Interest Group Name } & \multicolumn{1}{c|}{ Number of Interview Participants } \\
\hline Irrigation District Representatives & 1 \\
\hline Government Officials & 3 \\
\hline NGO Representatives & 5 \\
\hline Environmental Consultants & 3 \\
\hline Recreation Industry Professionals \& Enthusiasts & 3 \\
\hline
\end{tabular}

While these groupings represent the primary positionality of each participant to Deschutes Basin management issues, it is also important to note that outdoor recreation was noted as a driver for many a participant having decided to make central Oregon their home. The designations in the table above served as a means of ensuring I was collecting a wide range of perspectives on the issues I was researching but are 
not representative of the individual participants total breadth of views. In addition, while attempting to schedule additional interviews, I was informed by individuals I contacted that further sampling may prove difficult with certain interest groups as many organizations had already begun lawsuit preparation over the HCP itself, which may have prevented members of those organizations from participating in a recorded interview.

All 15 interviews in this dataset were conducted over the web-conferencing platform Zoom. Travel restrictions and health concerns due to the outbreak of COVID-19 necessitated the conducting of interviews remotely. A growing literature exists highlighting the effectiveness of conducting video interviews over virtual conferencing platforms such as Skype, Zoom and FaceTime (Deakin and Wakefield 2013; Lo Iacono, Symonds, and Brown 2016; Archibald et al. 2019). Researchers have documented that participants in virtual interviews via Zoom and Skype feel a strong sense of rapport with their conversation partners facilitated by their ability to respond to verbal and non-verbal cues (Lo Iacono, Symonds, and Brown 2016; Archibald et al. 2019). Zoom as a platform offered particular advantages to qualitative researchers through its internal audio-visual recording tools (Archibald et al. 2019). For this investigation, I utilized Zoom's cloud recording tools to capture audio, video and AI generated transcripts from each interview. Prior to recording any interview data, informed consent was obtained from interview participants via email, and then affirmed verbally before starting each interview. After each interview, I generated post-interview memos from my handwritten notes for use in later analysis and to 
document information not captured in transcripts. These memos then served as a guide for my preliminary code book.

Throughout the interview process, efforts will be made to maintain researcher reflexivity in order to ground the analysis of the interview data in the context in which it was collected. The nature of interview data is such that it is co-produced locally between interviewer and interviewee through the process of a conversation (Rapley 2004). In the initial development stages of this project it was understood that research would be able to take place on site in and around Bend, Oregon during the normal summer tourist season. This research was conducted in a time of significant economic uncertainty for the recreation and tourism industry in Central Oregon. Analyzing the impacts of COVID-19 on the Deschutes Basin was beyond my scope for this research, however there was no way for me to separate out those effects from the lived experiences of those I interviewed. In order to document the societal context in which this interview data was produced, I maintained a running research journal, documenting the progress of this research in the context of a rapidly changing sociopolitical landscape resulting from the COVID-19 outbreak in the United States.

\section{Analysis Methods}

Once transcribed, I imported all of my interview transcripts and memos into Atlas.ti, a qualitative data analysis software package, for coding and analysis. Before coding the interview transcripts, I developed a codebook (see Appendix D) through the open coding of my post-interview memos. All emergent themes relating to my research questions, collaborative governance, stakeholders, the Deschutes River, and 
river management were all added to this initial code book. I then coded my interview transcripts utilizing a "flexible coding" technique as described by Deterding and Waters (2018). First, I coded participant responses with broad index codes, breaking each transcript down by the themes outlined in the research instrument. After establishing the index codes, I then coded the transcripts using the codebook (Appendix D) stablished from my interview memos and adding open codes as they emerged in the data. When open coding of the interviews was complete, I then utilized Atlas.ti's code grouping functions to combine codes of similar themes; code groups all containing themes around stakeholder formation were added to a code group called "Defining Stakeholders" etc. I then utilized the code co-occurrence tools within Atlas.ti to analyze the relationships between different themes within code groups to analyze the associations between themes within code groups to conduct my analysis.

\section{Findings}

In Deschutes Basin collaborative governance, community groups becoming stakeholders is a two-step process. Stakeholders are understood to be those with a demonstrated material interest in the management of the Deschutes River, who then also actively participate in collaborative governance. What emerges between these two steps is a differentiation between groups that are understood to be entitled to stakeholder status, and groups that actually possess it by means of their participation in collaboration. In a majority of my interviews, it was understood that stakeholders 
were those that decided to "put on their stakeholder suits" and engage in the process of their own prerogative. However, the structure of collaborative processes, and the power structures under which they are developed may create barriers to certain community group's participation that may prevent their engagement. Different understandings of the Deschutes River as a place appear to select for which community groups do and do not decide to participate in collaboration, particularly in the recreation industry. The impacts of this differing sense of place, along with any barriers to participation presented by policymakers and the collaborative structures themselves appear to create a set of stakeholders in the Deschutes Basin different than those understood to be entitled to stakeholder status. In the following sections I explore each of these components in detail drawing on excerpts from my interviews. All of the participants quoted have been assigned pseudonyms (see Appendix C), with their occupational positionality described broadly as to avoid attribution of quotes to specific individuals.

\section{Entitlement to Stakeholder Status - "Demonstrated Interest"}

Throughout my interviews, the primary factor in determining stakeholder status for groups within the basin was the demonstration of "interest". Community groups were entitled to stakeholder status of their livelihoods or lifestyles would be directly impacted by changes in the management of the Deschutes River. Laura, a lobbyist working on behalf of the recreation industry said it succinctly, "a stakeholder is someone who has an actual stake in the outcome, like something to gain or something to lose." Those entitled to stakeholder status were those to whom changes 
in basin management practices pose risk to either material or lifestyle interests. In these situations, the "something to lose" often was not the river itself. Rather, the emphasis was placed upon risks to different community group's desired uses of Deschutes Basin water. The amalgam of entitlement to stakeholder status and perceptions of risk to material or social capital has generated a tiered understanding of stakeholder status. Those whose livelihoods are directly impacted by changes to river management understand themselves and others in their situation as having a more urgent voice in Deschutes Basin management than those whose derivation of value from the river is more oblique. This perception of risk to property and livelihood appears to satisfy the urgency and legitimacy stakeholder criteria described by Mitchel et al (1997).

Those lacking property interests are not dismissed out of hand, however the importance of their voice in decision making is held as ancillary due to their relatively lesser economic exposure. When discussing the variety of interests entitled to stakeholder status, Bob, a senior representative of a Basin irrigation district described it:

You know, that's a tough question because ... as someone supplying irrigation water, our water provides a livelihood. And so that could be seen as having more emphasis or more interest, but at the same time...the fly shop that sells flies to fisherman, He has an interest, his livelihoods impacted. Same with the tour groups. So ...it seems that those who have [an interest] that could affect their livelihood have much more at stake in this process than someone that likes to see the river flow by their house in the afternoon...but we do have representatives from both spectrums. And I guess you could tie... [the] value of the river and the water to property value as well. 
Here, Bob explicitly ties the concept of "interest" in the management of the basin to the property and livelihood of those deriving economic value from the river itself. Those who enjoy the river as an amenity are understood as having less of an interest in Basin management. Importantly, a distinction is made between an owner of the fly shop selling fishing equipment, and his customers who use that equipment for recreation. For Bob, income relying on a river related product constitutes a larger interest than those treating the river as an amenity. In response to the same question, Henry, a city official working in tourism echoed,"... my assumption would be that it was mostly people who were directly tied to the water, not so much the people who also just live in the community. Are the businesses and the old mill district a stakeholder?". From Henry's position, one's stakeholder interest appears proportional to the directness with which one's interests are tied to the river's flow. When discussing the role of property and risk determining stakeholders within the Habitat Conservation Plan, Tom, an environmental economic consultant familiar with Basin collaborative efforts said:

The whole process is driven by a law that's about endangered species. And so, the main stakeholders that end up in the process coming out of that are the...consumptive resource users who are ... the regulated party and species and other people are kind of off to the side.

In this understanding, the stakeholder with the most interest becomes the user whose primary use of the river is consumptive, in this case, the irrigation districts. The irrigation districts purpose, as an organization is to facilitate the delivery of the Basin's apportioned water to those holding the area's water rights. This activity is 
both generative of many livelihoods in the Deschutes Basin and a practice codified in state water law. Given the environmental impacts of the highly variable river stages these irrigation activities cause, engagement with the HCP process had been initiated to minimize financial exposure under the Endangered Species Act. While secondary users are understood to be "off to the side" in this process, Tom does recognize a separate set of primary users: the species within the river itself. Within both discourses of interest, species and habitat are understood to be primary users of water, however the focus on their utilization differs. As Tom describes, this recognition of in-stream stakeholders is a result of the legal liability present should they be ignored. A chairperson of a regional conservation organization described the relationship in a similar fashion, "there's a few interests that are direct, they have a stake in it and in our basin that usually falls under irrigation agriculture and there's a whole variety of that- Municipal water supply or instream interests.” Irrigation agriculture and instream species considerations appear entitled to stakeholder status due to the directness with which their material interests are attached to the flow regimes of the river itself. In this economized understanding of interest, this directness is what places these stakeholder interests above non-consumptive users like recreators. While not excluding those whose interest in the river are centered around their lifestyle, the proportion of stakeholder status an interest group is entitled to appears proportional to the fiscal ties that group has to the river itself. As summed up by Sam, a lifelong river guide, "Money. Money is the root of it all and people that can pay to play are going to have a bigger voice." 


\section{Stakeholder Status through Participation- Putting on the "Stakeholder Suit"}

While many community groups in the Deschutes Basin were understood as having some interest that would entitle them to stakeholder status, their actual becoming a "stakeholder" was frequently predicated on their active participation in collaborative efforts. As described by Tom, an interest group could not expect to be considered a stakeholder unless they decided to "put on their stakeholder suit" and engage in collaboration. Community groups having to actualize their stakeholder status by participation constrains the pool of potential stakeholders to those with the organizational strength to develop community visibility, and those individuals capable of managing the material strains and time-consuming nature of collaborative processes.

Tom, described the role of participation in the development of stakeholders within the Habitat Conservation Plan process:

I think the stakeholders that end up showing up, kind of put on their stakeholder suit, are regulated people who are party to [the] HCP. [They are] agencies who have some management responsibility, or formal interest groups that... have the resources and commitment to participate in the process.

From this perspective, an interest group's ability to participate as a stakeholder in collaboration is dependent on both the robustness of their organizational structure, and their willingness to commit to a process. To become stakeholders, an interest group would both have to possess a consciousness of themselves as a stakeholder in order to organize, and then become a party to collaboration. The contingency of stakeholder 
status on participation was reiterated by Bob when asked about participation in collaborative efforts, "[stakeholders ] have a vested...interest in what's going to happen and you're inclined to participate versus sitting back and doing nothing or waiting for a result that may not be a result...”. If stakeholders in this Basin's collaborative process are those that have the agency to participate, the question then emerges as to who does and does not have that ability or access. Those that are not present at the table may be understood to be "doing nothing" when, as Davis et al (2018) suggest, collaborative efforts are frequently staffed by those initiating them with parties approximately sharing their own interests. If participation is the tool by which stakeholder interests are validated, those assembling the collaborative efforts wield considerable power over the community groups legitimized as stakeholders. By conditioning “stakeholder" status on a community group's participation in a collaborative effort, while also functioning as the gatekeeper to that effort, agency for stakeholder determination is presented as being in the hands of those without the actual power to use it.

For community groups like those representing river recreation, this has played out in their being dismissed as stakeholders by virtue of their lack of participation. When discussing this conditionality, Tina, a representative of a major Oregon river conservation organization, when asked about recreation and stakeholder formation during the Habitat Conservation Plan observed:

Tina: To your point, I think they're very much stakeholders, but I think they weren't stakeholders until they saw a direct connection to their whitewater spots for the most part. 
Noel: So were they the stakeholders before they noticed?

Tina: No, I mean like Bend Paddle Trail Alliance was officially but they never showed up because I don't think it was that relevant and I also know it's not a paid staff, it's more a volunteer board. But the fly fishing community. man, those retired fly fishing volunteers come out in force and they get in it and they stick with it.

Stakeholders with an interest in water sports, despite having that interest, only became stakeholders in the process when they showed up to participate. Recreation advocacy groups like the Bend Paddle Trail Alliance, only became a stakeholder upon attending meetings. Only by participating in response to risks posed to their own recreation interests did their stakeholder status become legitimized. Additionally, Tina brings up the BPTA's organizational strength as an issue with their claims to stakeholder status, alluding to their being composed of volunteers as a potential liability in participating in collaboration. From her perspective, if they do not show up, they aren't stakeholders in Basin management, interest or no interest.

In addition to organizational struggles with participation, an individual or group's ability to navigate the time commitments required by collaboration may further select which community groups are understood to be stakeholders. Above, Tina describes the BPTA as absent in many collaborative efforts, while the fly fishing community, represented by mostly older Central Oregon residents are more reliably able to assert their stakeholder status. Rick, a fly fishing advocate described his experience of this kind of selection:

I spend an inordinate amount of time going to meetings and reading and researching water issues in Central Oregon ...That there's an 
element of what are the interests of the retired residents that have a lot of time to get involved in these things. There tends to be much more sort of a conservation, keep new people out, keep resource use down on that side of things... yeah, preservation over recreational development or recreation access. They're just a couple little sand beaches that Bend parks have built...those are just always so crowded and saturated, but generally, those people are too busy to go to meetings... They've got kids... they're not going to the public meetings at night, they're getting their kids in bed. There are a lot of ways that the most vocal are distorted from what is probably the most representative of total use and total value across the whole community.

The sentiment that time and family commitments may inhibit some community groups from participating in collaboration came up frequently when I asked participants about the river recreation industry's status as a stakeholder in the Basin. In this passage, Rick makes note that he, himself, has an "inordinate" amount of time to commit to participating in collaborative policy making whereas those with children are likely caring for their families rather than attending community meetings. Rick makes the observation that the time commitments required by collaboration may ultimately distort the views represented in the policymaking process. Rick also describes a difference in priority between older and younger voices in the community, with those having a longer tenure in the basin advocating for "preservation" of the current river status rather than advocating for change in current management practices.

These concerns were also brought up by Sam the river guide when answering the same question:

... as far as being a stakeholder I think is really important...You know there's these .. kind of people that sit in these high seat positions and are older. They kind of take care of their own and they keep making all the rules and the legislation because they've been there so long. I think 
there needs to be room for growth. I think there needs to be fresh young blood coming in with new ideas.

Sam makes the connection that interest groups and individuals with a longer tenure in the Basin have the ability to dictate the terms of collaboration and who does and does not participate. Her concern emerges from the recognition that the community interests represented by these long-standing community members may no longer be representative of the rapidly evolving landscape of interests held by newer residents of Central Oregon such as herself. Both Sam, Rick and other interview participants recognized this tension between stakeholders seeking "preservation" and a desire for "fresh, new ideas", however the collaborative process as it has occurred in the Deschutes Basin appears to favor longer standing community interests. Broadly, the time constraints created by lengthy collaborative processes and their constitutive meetings may serve to skew collaborative outcomes towards those desired by community members with the time to participate. Interests represented by volunteers or by people with external time commitments like family risk losing their status as stakeholders by virtue of an accommodating collaborative process, regardless of interest or risk. The process itself may be prohibitive to an interest putting on their "stakeholder suit" depending on their immediate life circumstances.

\section{Senses of Place \& Stakeholder Formation}

While the Deschutes Basin serves as the unit of analysis for this research, the basin does not itself exist as one uniform region in the minds of those that live, work and recreate there. Throughout my interviews, participants noted that the Deschutes 
River exists as many different places depending on the interest one has in it. Robert, a retired US Forest Service employee remarked:

The Deschutes river, the river is not one monolithic thing. It's like a multitude of different experiences. Everything from, you know, world class whitewater to lazy floating, you know, pool swimming water. You can find just about any experience that you want on a river somewhere on the Deschutes.

As Robert describes it, there exist a wide range of potential "experiences" available on the Deschutes River, however he also notes that these experiences may not all exist in the same location. Those seeking whitewater rapids on the Deschutes experience a very different river than those floating on inner-tubes through downtown Bend.

For many in the Basin, recreational opportunities are the lens through which the Deschutes River is experienced. Interview participants uniformly recognized that the ability of recreation to shape people's views of the Deschutes River as a place. This ubiquity was attributed primarily to the accessibility of recreation opportunities on the river and in the Basin broadly. When asked about what about the Deschutes River makes it such a draw for tourists and amenity migrants, Tom replied:

And so you have this sort of first class recreational amenity. And it is free and right in the middle of town...with great parks upstream downstream, you can take out here, you can take out there, you can put in here etc...You can paddleboard, you can swim. You can kayak. You can inner tube, you can river surf, ...It's fantastic. And it's a huge economic driver. When I was talking to some friends from Portland who came over... I lent them my inner tubes. It was on their checklist! That's what they wanted to do. So from an economic driver for the city of Bend in value, what people get out of it, it's absolutely enormous, 
and...not just the river, but all the access to mountains trails and everything here. ... It drives the whole community. It drives quality of life, and it drives people wanting to move here and live here ... they just say "Man, I can go surf in the morning before work and I can go ski in the afternoon and whatever!"

Tom describes the Deschutes River as an amenity "right in the middle of town", where those staying and living in Bend have access to a wide range of recreation opportunities a short distance from where they live. Public infrastructure around the river like public parks and floating launch points allow tourists and residents ease of access to the river itself, while also serving as a boon for the regional economy. Tom's friends, despite not being from the area, have floating the river "on their checklist" of things to do on their visit to Bend. To Tom, and other recreation focused interview participants, the accessibility of recreation opportunities to residents of Bend is a primary reason why they have chosen to live and work there.

As Robert described above however, the Deschutes River itself is not a homogeneous space. For people like Tom, who understand their quality of life being improved by their ability to "go surf in the morning before work", their perceptions of the river itself tend to focus on the spaces in which their recreation interests happen. Most of those spaces discussed are those most easily accessible from the urban center of Bend. A concern among those I interviewed who work in the conservation and environmental space is that this recreation focused sense of place held by many in the Basin works to obfuscate issues of river health, habitat destruction and river mismanagement. With many of the prominent recreation sites being focused around Bend, those experiencing the river only through those recreation opportunities may be 
unaware of environmental issues occurring elsewhere along the river. Tina, representative from a major river conservation organization explained this spatial constraining of perceptions of river health:

[There is a] spatial challenge of understanding those problems with the river because so much of the recreation is Bend based. With the white water rafting, tubing and kayaking, you literally would never know there's an issue if you're sitting in Bend and you're on the river in and around Bend. And so I think that's a huge reason why people aren't actively involved in those efforts, because they didn't know there was an issue and it wasn't impacting them because in the summertime the river gets diverted below Bend. It's hard to see, it goes into a canyon. Then in the winter it's above Bend like far above Bend where nobody really goes in the winter. And so, the stretch in Bend, its kind of like, "this is amazing. Why is there even a movement to restore the river?"

With so much of the region's recreation being focused on the population center of Bend, Tina notes that those only experiencing the river in that way and in those accessible places may not perceive any environmental issues with the river at all. In the summer months, water for irrigation is diverted from the main channel downstream of Bend, leaving high summer flows through the town and facilitating the recreation opportunities important to the city. The effects of this diversion are "hard to see" if a community member's perception of the river is based solely on their experiences near Bend. Tina postulates that this constrained sense of the river may be responsible for certain groups not participating in collaborative governance efforts, as community groups focused on the river as it appears through Bend may question why a movement exists to "restore" and differently manage the river. If in the eyes of a Bend whitewater kayaker the river appears in perfect health where they primarily 
utilize it, they may not see a point in participating in collaborative governance processes.

The challenges posed by this recreation focused sense of place were laid out starkly by Patrick, a representative of a different river advocacy organization, when asked about these spatially constrained perceptions of river health;

I think a lot of people you know, want to come here because of the river that appears to be healthy. This is one of my big pet peeves is that that big high flow that goes through town, it makes everyone think like there's just absolutely nothing wrong with the river and nobody even people who grew up here never connect in their brains that there's a river at the old mill, and then there's a river, the river house downstream and they're completely different because in between those two points $90 \%$ of the river got diverted and you have a river, a big huge river and then you have a creek. They're all the Deschutes River.

Patrick voices the same concern as Tina, that the robust flows through downtown Bend create an appearance of river health that may distort community perceptions of the river's health overall. From his perspective, even those who have lived in the Deschutes Basin their whole lives often fail to connect the Deschutes River as it flows through Bend and the irrigation networks into which it is diverted as the same system. With the river appearing healthy in the location at which it is most accessible, recreators and residents may assume that those conditions are maintained along the entire water way. As voiced by both Patrick and Tina, the concern then becomes people's reluctance to engage in river management issues if, based on their sense of place, the issue itself does not pose a risk to their personal interests. 
From my interviews, stakeholders in the management of the Deschutes Basin appear to be those with an at-risk property or lifestyle interest in the river, who then also engage in collaborative processes in which community input is solicited. Within this understanding, some participants proposed that differing perceptions of river health between community groups may filter which community groups perceive a risk to their interests and be spurred into participation. Tina mentioned this in a follow up to my question about the role of river recreation in Basin collaborative processes:

A lot of people that you mentioned, what struck me as if they haven't been involved in much so far. I think they are getting interested and need to be, but It's sort of the nature of where the problems on the river are- they have been a little bit removed from the whitewater community.

Being focused around the city of Bend, community groups like the whitewater kayaking community, or the Bend Paddle Trail Alliance, may not see changes in river management as directly impacting their interests. As a result, they may not see their participation in collaboration as necessary to protect those interests. Their lack of participation may be as much a function of their own sense of place as it is of the structure of the collaborative processes themselves.

This relationship between sense of place and collaborative participation appears inverted in discussions about the fly-fishing community. Being less geographically localized, the Deschutes River appeared to be a very different place to the angling community. Rick, a local fly-fishing advocate described his perception of the river: 
I spent a lot of time fishing and if you're out on rivers a lot like I am, then you start seeing the degradation of them, start seeing issues associated with them, you are seeing impacts on fish. And so I personally am the kind of person who will get involved with those sorts of things. When I see things that I believe need to be changed. And in Central Oregon there is a huge opportunity to get involved because there's a lot of issues. (original emphasis)

Rick, as an angler, describes himself as spending a considerable time out on the river in places where channel degradation due to irrigation flows is pronounced. He then correlates this perception of river degradation with his motivation to participate in basin governance. Tina also made this correlation stating "I think the fly fishing community has been very engaged because the upper river's been trashed." For the fly fishing community, their understanding of the Deschutes River as a larger place, beyond the boundaries of Bend, appears to increase their perceptions of risk to their interests, and catalyze their participation in Basin management efforts. Their sense of place emboldens them to don their "stakeholder suit".

\section{Competing Place Meanings}

At a higher level, from all of my interview participants, it became clear that co-constitutive of these different perceptions of the river as a place are a range of different ontologies of what the Deschutes river as a place is. For the agricultural community, the Deschutes River appears to exists foremostly as a resource from which value and a livelihood can be extracted. Many in the tourism and recreation industry see the river and basin as an "outdoor playground" from which amenity value and entertainment can be drawn. In the environmental space, there are then those that express concern with the basin's framing as an "outdoor playground" while also 
pushing back on its sole purpose as an agricultural utility, who argue that the extractive relationship that both the agricultural and recreation industry have with the basin pose challenges to the protecting of the Deschutes for use by endangered species and humans alike. In the section that follows I unpack each of these competing place meanings in turn, and explore the importance of these normative claims the river's purpose are a part of how each group understands themselves and others to become stakeholders.

First, to some, the Deschutes River serves as an economic driver and object from which monetary value is created and derived. Those with this understanding, when asked to describe what makes the Deschutes Basin such a draw for recreators and amenity migrants, couched their responses in language of "value" and appeals to the ways the strategic utilization of Basin resources can be leveraged for the enrichment of the regional economy. For people like Bob, the Deschutes River exists to provide income to himself and the agricultural community supported by the irrigation infrastructure he helps manage. For Henry, the river is an idea that can be marketed and mythologized to communities all over the world as a means of attracting tourist dollars to the region. Even when discussing the balance between agricultural interests and environmental concerns, Larry, an environmental economic consultant stated that "We know how much value you can get from the river from a habitat perspective, a recreation perspective and an amenity perspective." For both agriculture and recreation interests, the Deschutes River exists as something from which value is created; a property interest is born out of their fundamental understanding of what 
purpose the river has. Potential changes in the Deschutes River's ability to attain that purpose through policy shifts like the Habitat Conservation Plan may then catalyze community members to engage in collaborative policymaking to protect the river as they understand it.

Second, others interviewed held a place meaning of the Deschutes River as an "outdoor playground" which exists for the entertainment of locals and tourists and should be managed for maximum recreational benefit. While not divorced from the economic ontology of the river described above, this conceptualization places a strong emphasis on the means by which tourism, amenity migration and a continually increasing level of recreation accessibility has transformed a once rural community into a landscape in which high quality leisure activities exist around every corner. It was noted by Laura that the already proximal recreation opportunities to Bend are increasingly made more accessible through the economies of access created by rental businesses. She describes it:

"You can rent a bike, rent skis, rent a kayak like you, you could show up with nothing and be able to acquire all the supplies guides, whatever, because it has such a robust recreation economy. And I think you see similar examples in places like Aspen or Boulder. You know, those cities that just have everything there and you don't have to put a lot of effort into like being able to do something... And I think for most people that work nine to five jobs and have two days in a weekend, that matters. You don't want to spend all of your time trying to figure out how to get to the recreation opportunity. You just want to go there and do it and have a great time and then go back home."

The notion that the Deschutes Basin is a playground is reinforced, not by people's ability to recreate in the basin, but as Laura notes, by the ease with which those 
experiences can be obtained. The basin exists as a recreational destination to visit, have fun within and then leave behind sans care or consequences until the next window of free time arises.

This dynamic appears to function in the opposite direction as well, in which the notions of the "outdoor playground" are mythologized outwardly into other communities to bring people to the area. Henry recognized this, stating that:

There's this allure to what Bend is to so many people. There's this wonder. This is amazing and it's, It's aspirational. But to most people sitting in Portland, it's sort of a concrete jungle. But in Bend we always want to be talking about blue sky and fresh air and all the things Bend has going for it and really putting out that aspirational message like ""leave your phone behind", "get out of that concrete jungle", "get back to your roots".

Rather than being accessible to the point of being burdenless, the Deschutes Basin and Bend are presented as a place to which one can escape from the burdens of home. Through having traveled to a new place free from the structures and inauthenticity presented by the "concrete jungle", one, in the Deschutes Basin would have the liberty to eschew responsibilities altogether in an effort to connect with one's "roots". Even long term residents like Rick acknowledge that the place they live in is an "outdoor paradise", who's recreational opportunities and natural beauty are what enticed them to relocate.

Third, some participants felt that the trouble with framing the Deschutes Basin as a "paradise" or a "playground" is that those seeking either are seldom seeking the responsibility of taking care of such places. For some in the environmental 
community, the understanding of the Basin as an outdoor playground reframes the recreation industry as an extractive one. Alice, a representative from a Basin river advocacy organization articulated this when asked about the importance of recreation to the Basin's identity:

Alice: So, I mean, obviously, there's great recreation here, but it's been a very deliberate, and ongoing deliberate effort to bring people here for the sake of recreation... There was money to be made.

NV: Yeah, I just think about all of the infrastructure that's been put in to make all of the recreation super accessible.

Alice: And to me, it's that that's a huge environmental problem...I can't go down to the river because I see this constant bank erosion, pedestalled shrubs along the river that, you know, I mean I see so much damage and trampling and soil compaction and bank erosion, just in the years we've been here and it's getting worse and worse. I just think about wildlife. We're everywhere all the time. We've got mountain bikes that are able to go in the snow. We've got powered mountain bikes so that people can go places that they couldn't go in the past. So there's not even any respite in the winter and shoulder seasons. It just feels like a constant, constant assault on the river, the mountains and lakes.

For Alice, the development of infrastructure to make the basin's advertised recreation opportunities more available has begun to damage the river and surrounding environment in a manner akin to an extractive industry like logging. Through the development of this recreation infrastructure and advancements in recreation technology, people can suddenly be "everywhere"; there now exists much fewer area in which the river basin and its non-human inhabitants are left undisturbed.

Additionally, the building of structures like river walks dotted with "pedestalled shrubs" and river accesses along the shore increase the impact that recreators have on 
the physical environment through their compaction of bank soils, destruction of riparian vegetation and littering. Concerns about the immediate impacts of tourists on the river environment were echoed by Sam who voiced similar concerns about rafters and inner-tube floaters frequently littering on the banks and instream. For Sam, these "fast food rafters" did tend to treat the Deschutes River and Basin as a playground, rather than a place to be treated with care. From both of their perspectives, and as people that enjoy recreating in the river themselves, the portrayal of the Deschutes Basin as an "outdoor playground" has serious consequences as to who feels compelled to do something about its management.

\section{Discussion}

\section{The "Interest-Action" Process of Stakeholder Formation}

Based on my interviews, I identified a two-step process by which stakeholders are created in Deschutes Basin collaborative governance processes. First a community group had to demonstrate a property interest of some kind in the management of the

Deschutes River. Second, that group then had to participate in collaboration. I call this two-step process the "Interest-Action" process of stakeholder formation in a collaborative governance process. A group's participation in collaboration upon the demonstration of interest, however, is not a foregone conclusion, as access to the collaborative process may be stymied by various social, political and place-based constraints. Community interest groups that did not complete both steps were less 
likely to be recognized as stakeholders by other interest groups participating in water governance. This process is illustrated in Figure 3.

Figure 3 Interest-Action Process of Stakeholder Formation through Collaboration

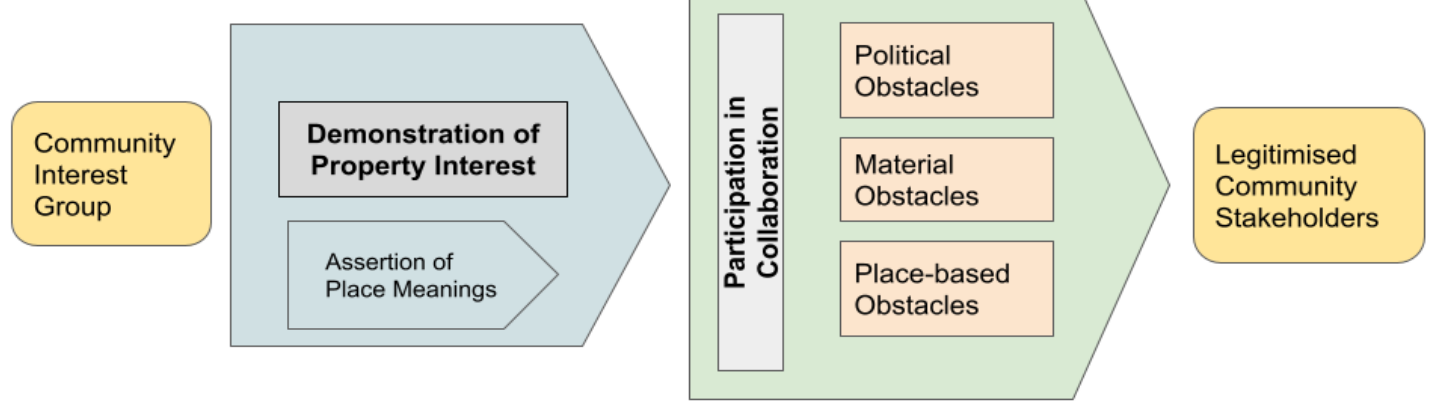

In step one, "property" as a category appears definitionally broad, ranging from direct financial and transactional relationships with the Deschutes River like agricultural water rights, to more loose kinds of lifestyle amenities like recreation access and scenic value. Regardless of the proximity of association, a community group's ability to demonstrate an "interest" emerged from the potential risks posed to their current state of being by proposed changes in the Deschutes River's management regimes. These property meanings, as articulated by interview participants appeared strongly associated with the place meanings ascribed to the Deschutes River as a whole. The property that a group may be deprived of because of changes in river management is inseparable from their normative understandings of what the Deschutes River's purpose, as a place, is. Broadly, an interest group's ascribed place 
meaning of a landscape, itself functions as a kind of property that can be impacted in the same manner as any other asset. The threatening of this property has been documented to spur other forms of political action (Ingalls et al. 2019, Enqvist et al 2019); in the Deschutes Basin, it appears to be the motivating force behind groups seeking to participate in collaborative governance and attempting to become understood as stakeholders within the collaborative process.

Having demonstrated a property interest, community groups, in order to be understood as collaborative stakeholders, are then required to participate in the collaborative process. Despite being the predicate action for an interest group to become a stakeholder, access to the collaborative table is not always a given. A multitude of obstacles may mitigate an individual or group's ability to actually get involved in the process. Interest groups may face political opposition to their participation by those organizing the collaborative effort, either through combative negotiation processes or simply not being brought to the table; the groups organizing the collaborative effort retain control over who does and does not participate.

Community groups faced material constraints on their participation in collaborative processes as well. Many interview participants made clear that collaboration is a lengthy, and time-consuming process. In the Deschutes Basin, these excised commitments of time and labor have selected for a group of collaborative participants who are generally older, with fewer familial responsibilities or those whose occupation allows them to participate in collaboration in a professional capacity. Many of the people I interviewed recognized that things like having young 
families, demanding jobs outside of the environmental space, or even just a stronger desire to be on the river than in a meeting kept them out away from the collaborative table. Many of those interviewed feeling encountering these material obstacles expressed concern that these constraints on their time, by inhibiting access to the collaborative process, may then exclude their interests from consideration and diminish their ability to be understood as stakeholders.

The last type of obstacles to participation that interview participants described were those explicitly tied to an individual or group's sense of the Deschutes River as a place. Depending on a community group's preferred use of the Deschutes River, the experiences of the river as a place varied heavily. To river recreators with an interest in floating, kayaking and swimming, the Deschutes River's robust flows through downtown Bend may leave otherwise environmentally conscientious people confused as to why movements exist to protect the river in the first place. Fisherpeople and environmental activists who venture beyond the population centers towards the river's many dams experience a very different place: they tell stories of riverbanks and riparian habitat being washed away by the high summer irrigation flows and of fish kills in the Deschutes River's tributaries when those flows are then shut off by the Basin's dams. For the environmental groups and recreators for whom the Deschutes River is a larger place, the perception of river health their range affords them may serve as a catalyst to participation as they perceive a risk to their ascribed place meaning. But for recreators and other community groups who's experience of the Deschutes River is centered around the Basin's urban center, the lack of apparent risk 
to their preferred place uses functions as an obstacle to their participating in collaboration. Broader place meanings also appear to be a factor, where one's participation in broader normative discourses of the river's purpose, like its being an “outdoor playground” or agricultural lifeline, may very much mediate one's willingness or ability to participate in collaboration. While many of the obstacles to participation in collaborative governance appear to be social or political, a group's willingness and ability to participate in collaboration appears to also have strong ties to the different senses of place held by such interest groups.

\section{Reconciling the Interest-Action Model with Existing Liteterature}

On its surface, the interest-action process of becoming a stakeholder through a collaborative governance process I observed through my interviews appears to draw components from all of the stakeholder models I examined in my review of the literature on stakeholder theories. Assertions of legitimacy and urgency and the power to actualize them as a stakeholder (Mitchell et al 1997), if framed as a process rather than a list of criteria, do roughly mirror the interest-action process described above. Sufficient power and felt urgency wielded by a community group may prove sufficient to overcome obstacles to collaboration. The classification of stakeholders into “definitive", "expectant" and "latent" stakeholders by Baunes et al (2004) also partially maps onto the proposed framework, where "definitive" stakeholders are those that complete both steps, "expectant" are those that may have demonstrated an interest but have not participated in collaboration, and "latent" are those that may have some interest but no desire to participate. Billgren and Holmen's (2008) cultural theory of 
stakeholder formation functions in a similar manner to the first step of the proposed model, where one first recognizes themselves based on cultural inputs as having a "stake" in the policy process. A diversity of cultural inputs certainly may account for the different place meanings and property interests held by community members seeking stakeholder status. The model proposed by May (2015), exploring the relationship between community groups differently abled to participate in policy making and their visibility as stakeholders, accounts for many of the political and social/material obstacles to participation faced by many groups who would otherwise understand themselves to be stakeholders. Despite it appearing differently on paper than the models proposed before it, the interest-action process of stakeholder formation through the collaborative process that has emerged from this research does appear to parallel much of the other research done in the development of stakeholder theories.

So then what do these established stakeholder theories fail to account for in the ways that stakeholders are formed in the Deschutes Basin through collaborative governance? From this research, I believe there are two important factors left out of the existing stakeholder theories that account for the manner in which stakeholders in the Basin appear to be formed compared to how they are theorized.

First, existing stakeholder theories, when applied to collaborative natural resource governance, do not put stakeholders "in place." Rather, stakeholders are established and convened to make policy decisions about places as if places are objective, physical objects. The dominant answer in my interviews to the question 
"what makes a stakeholder a stakeholder?" was someone who had something to lose, or someone with some property interest at stake in decisions made about Deschutes River management. That thing to be lost though, was often undivorceable from the place-meanings and place attachments held by the interview participant or those they were describing. For an interest group like the Basin's irrigation districts, the Deschutes River is a feature of the landscape from which economic value and a livelihood can be drawn through a landscape of irrigation infrastructure generations in the making. For fisherpeople and paddlers and other users, the Deschutes River may be their primary source of summer recreation right outside one's home in Bend, or even the catalyst to political action if the state of riparian habitats in the upper basin spur them to action. The challenge then emerges, as to how to reconcile the differences between potential stakeholders in the management of a place, where the place to be managed may be entirely different in the minds of all those being brought together. A collaborative governance scheme that, at its outset, begins with an assumption of what the essential function of a landscape is, may then alienate those who's place meanings differ from those assembling the collaborative. In a deeper manner than described by Davies et al (2017), rather than community groups being excluded from collaboration because their interests do not align with the convener of the collaborative, their exile may stem from a fundamental disagreement about the essential nature of the landscape being managed. In the Deschutes Basin, it would then make sense that an irrigation district may struggle to collaborate with, or even exclude an environmental group who does not believe the basin's purpose is not primarily to 
sustain agriculture. Two people may be sitting down to collaboratively craft policy governing a singular location in space, but each understand it to be two entirely different places. Recognizing that collaborative natural resource governance is happening "someplace" may then account for variability in stakeholder recognition unaccounted for in other stakeholder theories but evidenced in the Deschutes Basin.

Second, existing stakeholder theories, when applied to a collaborative process, assume the pre-existence of stakeholders. Instead, my research found that the collaborative process itself is a means by which stakeholders are created. There exists no essential quality that makes an interest group a stakeholder, rather their status as such is created through their relationships with the place they are in and the society in which they operate. A common refrain among interview participants was that "everyone is a stakeholder, but..." where the blank was filled with some stipulations about what interests should be accounted for. What these stipulations were, be it specific kinds of property interests, environmental concerns or recreational interests, they varied from person to person and group to group. Based on an individual's perceived positionality to the policy-making process, their consciousness of themselves and others as stakeholders was variable. In collaboratives in the Deschutes Basin, this is what makes participation so important. An interest group may have a consciousness of themselves as a stakeholder, but without their demonstration of that consciousness through participation, their status as a stakeholder may remain unrecognized by the collaborative process writ large. Documents like the Habitat Conservation Plan contain much language discussing the ways that stakeholder groups 
are brought together for collaborative efforts, however they do not acknowledge that the assembling of a collaborative effort, by recognizing specific community interests through participation, itself creates the stakeholders the effort is trying to assemble. Failing to recognize this co-constitutive process at play then places much power over legitimizing interests in a landscape in the hands of those assembling a collaborative effort; stakeholders would then become those chosen by the powerful rather than all those with an interest in decisions made about the management of a landscape.

These two concepts, when integrated with the existing literature on stakeholder formation, appear to much more completely account for the patterns of stakeholder formation in collaborative governance structures in the Deschutes Basin. The recognition that natural resource governance is as much a practice of managing places as it is governing objects brings into focus the important role that geographers have to play in the study of such collaborative systems; all of these actions happen someplace and natural resources all come from somewhere. By attempting to account for variability in senses of place held by community groups being assembled to collaborate, the proposed two-stage stakeholder formation model makes sense of the ways that some groups perceive themselves to be stakeholders in a place while others may leave them unrecognized or vice versa. Additionally, the understanding that stakeholders and collaboration are not mutually exclusive ideas, but instead are coconstitutive, makes clear the important role that critical studies of natural resource governance efforts have to play in illustrating the creation and reinforcement of power in a landscape through the creation of stakeholders via collaborative governance. By 
incorporating place into the way we understand how stakeholders in a landscape are formed, and recognizing that the processes that require "stakeholders" themselves create them, the interest-action process of stakeholder formation proposed above has utility in unpacking some of the complex stakeholder relationships existent in places the Deschutes Basin and collaborative efforts like those behind the Habitat Conservation Plan.

The River Recreation Community, Stakeholder Status \& Collaboration

This project was undertaken, initially, to explore the concerns of various Deschutes River recreation communities as to the potential disparate impacts on their interests proposed by the Habitat Conservation Plan. The Habitat Conservation Plan stands to reduce the artificially high summer flows on the Upper and Middle Deschutes that have become a boon to the region's river recreation opportunities. With potential impacts to their preferred uses of the river on the table, the paddlers and kayakers began to voice their concerns and network with environmental organizations in the basin; their raising these concerns is ultimately how this project came across my desk. Most interview participants, when asked about the river recreation community's status as a stakeholder said yes, paddlers, kayakers and rafters were definitely stakeholders of some kind. Some though, that were more directly involved with collaborative efforts, noted that the river recreation community, apart from fisherpeople, was seldom represented at the collaborative table. Despite having a demonstrable property interest in the management of the river, and being a robust part 
of the area's economy, the group was less frequently understood to hold stakeholder status by those participating in the collaborative efforts.

The river recreation community, it appears, was able to complete step one, but not step two of the two-step stakeholder formation process. Their property interest and assertion of place meanings are presented very clearly in things like the region's tourism marketing materials, reports of the region's economic structures, and even in less tangible places like place-meaning discourse of the region as an "outdoor playground". Changes in the recreation industry's access to the river as it is would put all of these property interests in jeopardy; that risk was broadly understood by those I interviewed. The missing piece appears to have been the river rec community's lack of participation in collaborative efforts.

When asked about their participation in collaborative governance, many of those I spoke to in the recreation community were all acutely aware of the material and political obstacles to their participation in collaboration. The majority of recreation advocates that I interviewed had other, full time jobs, and their attending extra community meetings was simply untenable while maintaining a work-life balance. Others who advocate for recreation interests told me that they had young kids, and simply would rather be spending time with them than being out on a school night at a community meeting. I was also told by many that they were simply not invited by the powers assembling the collaborative to participate. It was also made clear to me that for a large proportion of paddlers and kayakers, the Deschutes River as it flows through downtown Bend is a primary focus, limiting the scope of their 
perceptions of the river as a place. Given their encountering many or all of these obstacles, it makes sense that the collaborative process, in forming stakeholders, would select out community members like these in the river recreation community. By not participating, either by inability or unawareness, paddlers, kayakers and rafters then become a group who themselves have some stakeholder consciousness, but remain unrecognized as stakeholders by the powers assembling a collaborative governance effort. Through increased participation, those in these communities may be able to augment their voices in the policymaking process and begin to bridge that gap between their having a stakeholder consciousness and becoming widely recognized stakeholders themselves. 


\section{Conclusion}

The collaborative efforts surrounding the Habitat Conservation Plan afforded an important lens into the forces by which stakeholder status is determined through collaborations in the region. The language contained in the Habitat Conservation Plan works hard to present its drafting as a widely collaborative process by which all of the basin's potential interests had been considered. Given the river recreation community's alarm that their voices may not have been included, the breadth of the interests represented in the Plan remained a question, but one that political ecology is well equipped to answer.

In this thesis I have addressed questions of collaborative governance, stakeholder theories and the relationships between senses of place and engagement in environmental governance through my examination of case of the Habitat Conservation Plan. Through a series of semi-structured interviews with individuals involved in the collaborative water governance process in the Deschutes Basin, I have explored the ways by which they understood stakeholder status to emerge, their understandings of the Habitat Conservation Plan collaborative and the roles they thought senses of place may play in these perceptions. Through these interviews, I did find answers to my initial research questions, and a model to illustrate the stakeholder formation process in this specific case. In this final section, I sum up the answers to these specific questions in turn, and then conclude with my thoughts on future 
research directions and the contributions made in this work to the field of political ecology.

Addressing the Research Questions

How are "stakeholders" in Deschutes Basin management determined and legitimized in collaborative resource governance processes?

In Deschutes Basin collaborative water governance, stakeholder formation appears to be a two-step process. First, a community group must present a property interest in the management of Deschutes Basin water. Second, a group with such interest must then actively participate in collaborative efforts. The assertion of a group's property interest was often inseparable from their claims to a normative placemeaning of the Deschutes Basin, where the property a group stood to loose was often wrapped up in what they believe is the basin's purpose or best use. In step two of the process, a group's ability to participate was often mediated by political, material and place-based obstacles that prevented them from engaging in collaborative governance processes. These obstacles to participation meant that a community group could understand themselves to have a property interest and possess stakeholder status, but not ultimately by understood as such should they not be able to participate. This "Interest-Action" model of stakeholder formation through collaboration demonstrates that the collaborative process itself is generative of stakeholder status in a landscape, while at the same time being dependent upon the existence of stakeholders; broadly, collaborative governance and stakeholders are co-constitutive phenomena in Deschutes Basin collaborative water governance. 


\section{What is the river recreation community's relationship to the collaborative}

\section{water governance process in the Deschutes Basin?}

The river recreation community, kayakers, rafters, paddlers, and other water recreation enthusiasts, all have a substantial property interest in the management of the Deschutes Basin. Changes in river flow proposed in the Habitat Conservation Plan present risks to the river states from which many recreators derive value from the river. In collaborative processes like the Habitat Conservation Plan, the river recreation industry recognized themselves as having a property interest in the Basin's management, however they were less able to participate in collaborative processes and thus held less status as stakeholders in the Basin. The good news for river recreation interest groups though, is that stakeholder status does not appear to be a fixed thing. The interest-action model illustrates that in these situations, stakeholder status is a process of becoming; a group's lack of status in the moment is not destiny. This means that the solution to building more stakeholder status for river recreation groups may just be to work at navigating around their obstacles to participation. Through endeavoring to participate more fully in collaborative efforts, recreation industry interest groups may be able to more regularly guarantee their seat at the collaborative table.

What role does sense of place play in the construction of stakeholder status in the Deschutes Basin/Central Oregon? 
Different senses of place and place-meanings appear to factor into both steps of stakeholder formation in the Deschutes Basin. For an interest group demonstrating a property interest in Basin management, their assertion or claims to some kind of property, be it a water right or a scenic view, were always tied to what that group's understood place meaning. When a group's preferred use the Deschutes River became threatened by changes in management practices, that group then tended to understand themselves as having a property interest. In many ways, an individual group's place meaning for the Deschutes behaved like a property object itself, but the exploration of that relationship is beyond the scope of this research. The role of different senses of place shaping stakeholder formation was also apparent in the ways different perceptions of river health based on different preferred uses led to different outcomes in collaborative participation. Those that did not see the river as needing any changes in management practices by virtue of their only spending time in places with less apparent damage may have been less incentivized to participate in collaboration.

\section{Further Research}

In pursuit of the answers to these research questions, a secondary theme emerged that I intend to explore in further research. In the Deschutes Basin, the irrigation districts composing the Deschutes Basin Board of Controls hold the majority of the region's water rights. Given their authority over the Basin's water, many in my interviews raised concerns that it was often the irrigation districts themselves who were the one's assembling these collaborative efforts. Further, numerous interview participants indicated a revolving pattern of water collaboratives 
generating recommendations for habitat protection that would then be ignored by irrigators, who then, in turn create a new water management collaborative. This raised some concerns as to the motives behind the assembly of collaborative water governance structures, and the disciplining power that the present water rights regime has on the effectiveness of collaborative processes in the Basin. It is my intention to re-examine the interview data collected in this study in pursuit of these emerging legal-geography research questions.

\section{Reflections on the Project and Context}

At the outset of this project, in January of 2020, my vision for this project looked very different. Those early plans involved frequent weekend trips to Bend and the Deschutes Basin, long interviews with people in person, and much time spent splashing around in the Deschutes River myself. I had ambitions of exploring a part of Oregon that fascinates me, and to really prove to myself that I could do qualitative research in human geography. As I was planning to formally kick off this research, the COVID-19 pandemic began to take hold in earnest across the country, which meant I had to make some pretty drastic changes to my plans. Suddenly a summer spent in central Oregon with interviews in person became a summer alone in my 400 square foot apartment learning how to interview people through a computer. Pivoting to the use of zoom for these interviews afforded me some unique opportunities to have some conversations that may have otherwise been difficult to schedule, while also bringing the cost of doing this work down considerably as buying gas or lodging was no longer 
a concern. In my own experience, the concern very quickly became the loneliness and isolation that came from working on this project for an entire summer in one small apartment all by myself.

The undiscriminating and deep reaching scope of the COVID-19 pandemic meant that there was not a single person or situation I interacted with in this research that was not affected in profound ways. Interviews that normally would have been conducted in professional spaces were now happening living room to living room. In many circumstances curios children and wandering pets joined our meetings unexpectedly. Many of those I spoke to, especially those attached to the basin's many recreation and tourism industries were taking the time to speak with me while the Basin was suffering through a summer with many fewer tourists. The difficulties and sadness brought about by COVID-19 was a subject in every interview I conducted. In a different year, under different circumstances, this project may turn out quite differently.

It is also worth noting that 2020, in addition to dealing with the COVID-19 pandemic was also a presidential election year, and also saw one of the largest protest movements in US history erupt in opposition to systemic police brutality across the country. While national politics seldom earned more than a passing comment at the beginning or end of an interview, the media coverage of protests in downtown Portland, OR over the summer of 2020 did appear to have some impacts on my interview participants views of myself as a researcher being from the city. This posed some challenges, especially at the start of interviews as I often felt compelled to 
describe my experiences of living in the city through those moments, while being mindful of the politically charged discourses of those event's presentation in places outside the city. It was a challenge to make sure that my interview participants did not feel alienated by anything I might say about my circumstances. Ultimately, some of the dialogues I had with interview participants about the events in Portland worked for building rapport quickly before the formal interview process had even begun.

In total, the experience of doing this research has been wild, but rewarding. Having to move data collection to a remote platform meant that I was forced to learn new research methods and new technological approaches at the same time, but I was also able to access more individuals than I would have otherwise. The tragedy that is COVID-19 had touched the lives of everyone I spoke with in this project, but the shared experience did seem to create common ground from which to start a conversation. In the future, I think that remote interviews will remain a prominent tool in my research methods toolkit, however I do hope that I will be using them because they are the best tool for the work, not the only one permittable under tragic circumstances. This project, as it appears now, is very different than I envisioned it at the outset, however I do not think the substance of what I have learned would be the same given it taking place in any other way.

\section{Final Thoughts}

In December of 2020, the US Fish \& Wildlife Department approved the Deschutes Basin Habitat Conservation Plan. After more than a decade of work on behalf of the applicants, collaborative participants, government officials and 
environmental activists, the text in that document became policy. In this research, I have explored the ways that a process like the Habitat Conservation Plan can create stakeholders and shape stakeholder status. Through the illustration of the "InterestAction" model of stakeholder formation I have then demonstrated how that shaping takes place. The challenging thing for myself, as a researcher, is that now the collaborative process I have been examining is complete; the collaboration is over and the efforts of all those involved have been codified and the voices of those not included have been left out with the ink on the document having dried. So then what is to be done with this work? This research contributes to the existing literature on stakeholder theories by proposing a new model by which stakeholders are formed in collaborative processes. While in its current form, this model has been constructed on data from one specific location, the application and modification of this model in other case studies of collaborative processes may prove fruitful in unpacking how those processes work. Through the application of this model in other places, further research may also highlight the dynamic and important role that competing senses of place play in the management of natural resources. The dimension of place in these stakeholder processes does then position human geographers and political ecologists in a unique position to work on these issues, and to contribute to the improvement of collaborative natural resource governance processes. Through further work in this field by such researchers, perhaps these processes can be improved such that a group whose notion of a place is threatened by changes in resource management can ensure their voices are heard before the important work is finished. Natural resources, while often 
discussed as objects and managed as such, are all someplace, and often a someplace that means a lot to someone. 


\section{References}

About Us | Central Oregon Irrigation District. https://www.coid.org/about-us/ (last accessed 21 March 2020).

Ansell, C., and A. Gash. 2007. Collaborative Governance in Theory and Practice. Journal of Public Administration Research and Theory 18 (4):543-571.

Archibald, M. M., R. C. Ambagtsheer, M. G. Casey, and M. Lawless. 2019. Using Zoom Videoconferencing for Qualitative Data Collection: Perceptions and Experiences of Researchers and Participants. International Journal of Qualitative Methods 18:1609406919874596.

Billgren, C., and H. Holmén. 2008. Approaching reality: Comparing stakeholder analysis and cultural theory in the context of natural resource management. Land Use Policy 25 (4):550-562.

Buanes, A., S. Jentoft, G. Runar Karlsen, A. Maurstad, and S. Søreng. 2004. In whose interest? An exploratory analysis of stakeholders in Norwegian coastal zone planning. Ocean \& Coastal Management 47 (5):207-223.

Crooked River Watershed Council. HOME. Mission Statement. https://www.crwc.info (last accessed 8 May 2020).

Dakins, M. E., J. D. Long, and M. Hart. 2005. Collaborative Environmental Decision Making in Oregon Watershed Groups: Perceptions of Effectiveness 1. Journal of the American Water Resources Association 41 (1):171-180.

Davenport, M. A., J. E. Leahy, D. H. Anderson, and P. J. Jakes. 2007. Building Trust in Natural Resource Management Within Local Communities: A Case Study of the Midewin National Tallgrass Prairie. Environmental Management 39 (3):353-368.

Davidson, H. R. 2005. Bent to nature: Bend, Oregon as a case study in twentiethcentury property development. http://search.proquest.com/docview/305406556/abstract/1B386028A7294316P Q/1 (last accessed 14 March 2020).

Davies, A. L., and R. M. White. 2012. Collaboration in natural resource governance: Reconciling stakeholder expectations in deer management in Scotland. Journal of Environmental Management 112:160-169.

Davis, E. J., L. K. Cerveny, D. R. Ulrich, and M. L. Nuss. 2018. Making and Breaking Trust in Forest Collaborative Groups. Humboldt Journal of Social Relations 40:211-231. 
Davis, E. J., E. M. White, L. K. Cerveny, D. Seesholtz, M. L. Nuss, and D. R. Ulrich. 2017. Comparison of USDA Forest Service and Stakeholder Motivations and Experiences in Collaborative Federal Forest Governance in the Western United States. Environmental Management; New York 60 (5):908-921.

DBBC. About. Deschutes Basin Board of Control. http://dbbcirrigation.com/about/ (last accessed 21 March 2020).

Deakin, H., and K. Wakefield. 2013. Skype interviewing: reflections of two PhD researchers: Qualitative Research. http://journals.sagepub.com/doi/10.1177/1468794113488126?icid=int.sj-fulltext.similar-articles.1 (last accessed 25 April 2020).

DeLyser, D. 2001. When Less is More: Absence and Landscape in a California Ghost Town. In Textures in Place: Exploring humanist geographies, 22-40. Minneapolis: University of Minnesota Press.

Deschutes Basin Board of Controls. 2019. DBHCP Entire Document August 2019.pdf. Deschutes Basin Habitat Conservation Plan. https://www.fws.gov/oregonfwo/Documents/DeschutesHCP/deisFR/DBHCP\% 20Entire\%20Document\%20August\%202019.pdf (last accessed 9 March 2020).

Deschutes River. 2014. Whitewater Guidebook. https://www.whitewaterguidebook.com/oregon/deschutes-river/ (last accessed 14 March 2020).

Deschutes River Conservancy Reauthorization Act of 2005 :report (to accompany S. 166). 2005. [Washington, D.C. : http://hdl.handle.net/2027/umn.31951d02536089m.

Deterding, N. M., and M. C. Waters. 2018. Flexible Coding of In-depth Interviews: A Twenty-first-century Approach. Sociological Methods \& Research :0049124118799377.

Dowling, R., K. Lloyd, and S. Suchet-Pearson. 2016. Qualitative methods 1. Progress in Human Geography 40 (5):679-686.

Enqvist, J. P., L. K. Campbell, R. C. Stedman, and E. S. Svendsen. 2019. Place meanings on the urban waterfront: a typology of stewardships. Sustainability Science 14 (3):589-605.

Ewick, P., and S. S. Silbey. 1998. The Common Place of Law: Stories from Everyday Life. University of Chicago Press. 
Fernandez, S. 2014. Much Ado About Minimum Flows...Unpacking indicators to reveal water politics. Geoforum 57:258-271.

Grimble, R., and K. Wellard. 1997. Stakeholder methodologies in natural resource management: a review of principles, contexts, experiences and opportunities. Agricultural Systems 55 (2):173-193.

Home. Trout Unlimited. https://ww.tu.org/ (last accessed 19 March 2020).

Ingalls, M. L., A. Kohout, and R. C. Stedman. 2019. When places collide: power, conflict and meaning at Malheur. Sustainability Science 14 (3):625-638.

Innes, J. E., and D. E. Booher. 2004. Reframing public participation: strategies for the 21st century. Planning Theory \& Practice 5 (4):419-436.

Johnstone, B. 1990. Stories, Community and Place. Indiana University Press.

Levesque, V. R., A. J. K. Calhoun, K. P. Bell, and T. R. Johnson. 2017. Turning Contention into Collaboration: Engaging Power, Trust, and Learning in Collaborative Networks. Society \& Natural Resources 30 (2):245-260.

Lo Iacono, V., P. Symonds, and D. H. K. Brown. 2016. Skype as a Tool for Qualitative Research Interviews. Sociological Research Online 21 (2):103117.

Manion, J. An enterprise of the Confederated Tribes of the Warm Springs Reservation. :37.

May, C. K. 2015. Politics of visibility: competing for legitimacy in North Carolina fisheries governance. Environment and Planning C: Government and Policy 33 (6):1484-1500.

Mitchell, R. K., B. R. Agle, and D. J. Wood. 1997. Toward a Theory of Stakeholder Identification and Salience: Defining the Principle of Who and What Really Counts. Academy of Management Review 22 (4):853-886.

NEPA | National Environmental Policy Act - Collaboration Handbook. 2007. https://ceq.doe.gov/get-involved/collaboration_handbook.html (last accessed 17 March 2020).

O'Connor, H., C. Madge, R. Shaw, and J. Wellens. 2008. Internet-based Interviewing. In The SAGE Handbook of Online Research Methods, 271-289. 1 Oliver's Yard, 55 City Road, London England EC1Y 1SP United Kingdom: SAGE Publications, Ltd http://methods.sagepub.com/book/the-sage-handbook-ofonline-research-methods/n15.xml (last accessed 25 April 2020). 
O'Connor, J., G. Grant, and T. Haluska. 2013. Overview of geology, hydrology, geomorphology, and sediment budget of the Deschutes River Basin, Oregon.

Oregon Travel Impacts: 1991 - 2018, Dean Runyan Associates. 2019. Travel Oregon. https://industry.traveloregon.com/resources/research/oregon-travel-impacts1991-2011-dean-runyan-associates/ (last accessed 21 March 2020).

ORS 541.910 - Voluntary local watershed councils - 2017 Oregon Revised Statutes. https://www.oregonlaws.org/ors/541.910 (last accessed 8 May 2020).

Paretchan, L. M. 2010. Water resource management strategies : Deschutes Basin, Oregon. :72.

Pedersen, E. R. 2006. Making Corporate Social Responsibility (CSR) Operable: How Companies Translate Stakeholder Dialogue into Practice. Business and Society Review 111 (2):137-163.

Pilz, R. D. 2006. At the Confluence: Oregon's Instream Water Rights Law in Theory and Practice Comment. Environmental Law 36 (4):1383-1420.

Rapley, T. 2004. Interviews. In Qualitative Research Practice, 16-34. 1 Oliver's Yard, 55 City Road, London England EC1Y 1SP United Kingdom: SAGE Publications Ltd http://methods.sagepub.com/book/qualitative-researchpractice/d5.xml (last accessed 25 April 2020).

- 2007. Doing Conversation, Discourse and Document Analysis. 1 Oliver's Yard, 55 City Road, London England EC1Y 1SP United Kingdom: SAGE Publications Ltd. http://methods.sagepub.com/book/doing-conversationdiscourse-and-document-analysis (last accessed 25 April 2020).

Relph, E. C. 1976. Place and placelessness. London: Pion.

Robbins, P. 2012. Political ecology: a critical introduction 2nd ed. Chichester, West Sussex; Malden, MA: J. Wiley \& Sons.

Rood, S. B., C. George, B. George, and W. Tymensen. 2006. Instream flows for recreation are closely correlated with mean discharge for rivers of western North America. River Research and Applications 22 (1):91-108.

Satein, H. R. 2017. Fighting to Cooperate: Litigation, Collaboration, and Water Management in the Upper Deschutes River Basin.

Scott, D. 2003. Climate Change and Tourism in the Mountain Regions of North America.

Seale, C. 2012. Using Software to Analyze Qualitative Interviews. In The SAGE Handbook of Interview Research: The Complexity of the Craft, 427-440. 2455 
Teller Road, Thousand Oaks California 91320 United States: SAGE Publications, Inc. http://methods.sagepub.com/book/handbook-of-interviewresearch-2e/n30.xml (last accessed 7 May 2020).

Silbey, S. S. 2005. After legal consciousness. Annual Review of Law and Social Science 1 (1):323-368.

Singleton, S. 2002. Collaborative Environmental Planning in the American West: The Good, the Bad and the Ugly. Environmental Politics 11 (3):54-75.

State of Oregon: Department of Environmental Quality - Home. https://www.oregon.gov/DEQ/Pages/index.aspx (last accessed 19 March 2020).

Stedman, R. C. 2016. Subjectivity and social-ecological systems: a rigidity trap (and sense of place as a way out). Sustainability Science 11 (6):891-901.

Stokowski, P. A. 2002. Languages of place and discourses of power: Constructing new senses of place. Journal of Leisure Research 34 (4):368-382.

Tourism | City of Bend. https://www.bendoregon.gov/government/departments/economicdevelopment/tourism (last accessed 10 March 2020).

Tuan, Y.-F. 1990. Topophilia: A Study of Environmental Perceptions, Attitudes, and Values. New York, UNITED STATES: Columbia University Press. http://ebookcentral.proquest.com/lib/psu/detail.action?docID=3029399 (last accessed 16 January 2021).

U.S. Census Bureau QuickFacts: Bend city, Oregon. https://www.census.gov/quickfacts/fact/table/bendcityoregon/PST045219 (last accessed 9 April 2021).

U.S. Census Bureau QuickFacts: Redmond city, Oregon. https://www.census.gov/quickfacts/fact/table/redmondcityoregon/PST045219 (last accessed 9 April 2021).

Veldhuizen, M. T., Bolk, V, and Dentoni, D. 2012. Multi-stakeholder interaction as a source for sustainable development: organisational drivers determining firms' 'stakeholder dialogue' and 'knowledge integration' capabilities. Proceedings of the 22nd Annual World Symposium of the International Food and Agribusiness Management Association (IFAMA :24. 
WAFWO - Oregon Spotted Frog. https://www.fws.gov/wafwo/articles.cfm?id=149489589 (last accessed 21 March 2020).

Walker, P. A. 2005. Political ecology: where is the ecology? Progress in Human Geography 29 (1):73-82.

WaterWatch Oregon- Home. WaterWatch. https://waterwatch.org/ (last accessed 19 March 2020).

What is ATLAS.ti. ATLAS.ti. https://atlasti.com/product/what-is-atlas-ti/ (last accessed 7 May 2020).

Whittaker, D., and B. Shelby. 2002. Evaluating Instream Flows for Recreation: Applying the Structural Norm Approach to Biophysical Conditions. Leisure Sciences 24 (3-4):363-374. 


\section{Appendix A: Table of Acronyms \& Initialisms}

\begin{tabular}{|l|l|}
\hline Abbreviation & Name \\
\hline DBBC & Deschutes Basin Board of Control \\
\hline DBHCP & $\begin{array}{l}\text { Deschutes Basin Habitat } \\
\text { Conservation Plan }\end{array}$ \\
\hline NEPA & $\begin{array}{l}\text { National Environmental Protection } \\
\text { Agency }\end{array}$ \\
\hline ESA & Endangered Species Act \\
\hline COID & Central Oregon Irrigation District \\
\hline USFS & United States Forest Service \\
\hline BoR & Bureau of Reclamation \\
\hline BLM & Bureau of Land Management \\
\hline ODEQ & $\begin{array}{l}\text { Oregon Department of Environmental } \\
\text { Quality }\end{array}$ \\
\hline OWRD & Oregon Water Resources Department \\
\hline OWEB & $\begin{array}{l}\text { Oregon Watershed Enhancement } \\
\text { Board }\end{array}$ \\
\hline OTIR & Oregon Tourism Impact Report \\
\hline HRRP & Human Resources Protection Plan \\
\hline
\end{tabular}




\title{
Appendix B: Interview Instrument
}

\author{
Interview Guide
}

1) Most Important Issues

a) What factors do you think determine "stakeholder" status in Deschutes Basin management?

b) What does the river recreation community mean to the Deschutes Basin today?

2) The Deschutes Basin Habitat Conservation Plan

a) What have been your experience working with or dealing with collaborative governance

b) structures in the Basin?

c) What are your thoughts on the DBHCP?

i) What impacts do you see resulting from the plan's proposed changes?

ii) How representative do you think the DBHCP is of the all of the Basin's interest?

iii) How effective do you think collaborative processes like that in the DBHCP are?

(1) Do you feel like the DBHCP was a good example of collaborative governance?

3) River Recreation Community \& Stakeholder Status

a) What about the Deschutes River and central Oregon do you think makes it such a draw for tourists and new residents?

b) Why do you think people choose to spend their time here, vs other growing exurban recreation hubs?

c) What does the river recreation community mean to the Deschutes Basin?

i) How has this meeting evolved over time? Is it different now than it used to be?

ii) Is the river recreation community a "stakeholder" in the Deschutes Basin?

(1) How do you make this determination?

4) Networks/Perceptions of Stakeholder Status

a) Who do you see as being the stakeholders with the most power in the Deschutes Basin?

b) Who else do you think I should talk to in order to understand these issues better?

c) Who do you generally agree and disagree with? 


\section{Appendix C: Participant List by Pseudonym}

\begin{tabular}{|l|l|}
\hline Participant Pseudonym & Professional Positionality \\
\hline John & Environmental Economist \\
\hline Patrick & NGO Representative \\
\hline Tina & NGO Representative \\
\hline Rick & Environmental Activist \\
\hline Laura & $\begin{array}{l}\text { NGO Representative / Policy } \\
\text { Advocate }\end{array}$ \\
\hline Henry & $\begin{array}{l}\text { City Affiliated Non-Profit } \\
\text { Representative }\end{array}$ \\
\hline Sam & River Recreation Professional \\
\hline Robert & Former Government \\
Professional
\end{tabular}




\section{Appendix D: Atlas.ti Codebook}

\begin{tabular}{|c|c|c|c|}
\hline Code & Comment & $\begin{array}{l}\text { Code Group } \\
1\end{array}$ & $\begin{array}{l}\text { Code Group } \\
2\end{array}$ \\
\hline \multicolumn{4}{|l|}{$\begin{array}{l}\text { "Hard Work" in River } \\
\text { Advocacy }\end{array}$} \\
\hline \multicolumn{4}{|l|}{$\begin{array}{l}\text { "If They Knew, They'd } \\
\text { Be Here" }\end{array}$} \\
\hline & & & \\
\hline "The Tribes" & & $\begin{array}{l}\text { Important } \\
\text { Actors }\end{array}$ & \\
\hline Agriculture & & $\begin{array}{l}\text { Important } \\
\text { Actors }\end{array}$ & \\
\hline \multicolumn{4}{|l|}{$\begin{array}{l}\text { Agriculture vs } \\
\text { Environment }\end{array}$} \\
\hline Amenity Migrants & & $\begin{array}{l}\text { Different } \\
\text { Imaginaries } \\
\text { of Central } \\
\text { Oregon }\end{array}$ & \\
\hline \multirow{2}{*}{\multicolumn{4}{|c|}{$\begin{array}{l}\text { Appeals to Democracy } \\
\text { Appeals to Impericism }\end{array}$}} \\
\hline & & & \\
\hline \multicolumn{4}{|l|}{ BPTA } \\
\hline Breweries & & $\begin{array}{l}\text { Important } \\
\text { Actors }\end{array}$ & \\
\hline CftD - Inneffective & & $\begin{array}{l}\text { Important } \\
\text { Actors }\end{array}$ & \\
\hline CftD- Affraid to Push & & $\begin{array}{l}\text { Important } \\
\text { Actors }\end{array}$ & \\
\hline \multicolumn{4}{|l|}{ Common Ground } \\
\hline $\begin{array}{l}\text { Competing Imaginaries } \\
\text { of } \mathrm{CO}\end{array}$ & & $\begin{array}{l}\text { Different } \\
\text { Imaginaries } \\
\text { of Central } \\
\text { Oregon }\end{array}$ & \\
\hline $\begin{array}{l}\text { Competing Scopes of } \\
\text { Stakeholder }\end{array}$ & & $\begin{array}{l}\text { Defining } \\
\text { Stakeholder }\end{array}$ & \\
\hline Cost Benefit Analysis & & & \\
\hline COVID & & & \\
\hline $\begin{array}{l}\text { Defining Stakeholder- } \\
\text { Organizational Strength }\end{array}$ & & $\begin{array}{l}\text { Defining } \\
\text { Stakeholder }\end{array}$ & \\
\hline $\begin{array}{l}\text { Defining Stakeholders - } \\
\text { Context Specific }\end{array}$ & & & \\
\hline
\end{tabular}




\begin{tabular}{|c|c|c|}
\hline \multirow{3}{*}{$\begin{array}{l}\text { Defining Stakeholders - } \\
\text { NonHuman } \\
\text { Stakeholders } \\
\text { Defining Stakeholders - } \\
\text { Public Ownership } \\
\text { Defining Stakeholders - } \\
\text { Tenure }\end{array}$} & & \\
\hline & $\begin{array}{l}\text { Defining } \\
\text { Stakeholder }\end{array}$ & \\
\hline & $\begin{array}{l}\text { Defining } \\
\text { Stakeholder }\end{array}$ & \\
\hline $\begin{array}{l}\text { Defining Stakeholders- } \\
\text { Economic Power }\end{array}$ & $\begin{array}{l}\text { HCP } \\
\text { Stakeholders } \\
\text { - Who } \\
\text { Should vs } \\
\text { Who Was }\end{array}$ & \\
\hline $\begin{array}{l}\text { Defining Stakeholders- } \\
\text { Interest }\end{array}$ & $\begin{array}{l}\text { Defining } \\
\text { Stakeholder }\end{array}$ & $\begin{array}{l}\text { HCP } \\
\text { Stakeholders } \\
\text { - Who } \\
\text { Should vs } \\
\text { Who Was }\end{array}$ \\
\hline $\begin{array}{l}\text { Defining Stakeholders- } \\
\text { Participation }\end{array}$ & $\begin{array}{l}\text { Defining } \\
\text { Stakeholder }\end{array}$ & $\begin{array}{l}\text { HCP } \\
\text { Stakeholders } \\
\text { - Who } \\
\text { Should vs } \\
\text { Who Was }\end{array}$ \\
\hline $\begin{array}{l}\text { Defining Stakeholders- } \\
\text { Property }\end{array}$ & $\begin{array}{l}\text { Defining } \\
\text { Stakeholder }\end{array}$ & $\begin{array}{l}\text { HCP } \\
\text { Stakeholders } \\
\text { - Who } \\
\text { Should vs } \\
\text { Who Was }\end{array}$ \\
\hline $\begin{array}{l}\text { Defining Stakeholders- } \\
\text { Sense of Place }\end{array}$ & $\begin{array}{l}\text { Defining } \\
\text { Stakeholder }\end{array}$ & \\
\hline $\begin{array}{l}\text { Defining Stakeholders- } \\
\text { Tiers of Stakeholders }\end{array}$ & $\begin{array}{l}\text { Defining } \\
\text { Stakeholder }\end{array}$ & \\
\hline Deschutes Basin Study & $\begin{array}{l}\text { Important } \\
\text { Actors }\end{array}$ & \\
\hline $\begin{array}{l}\text { Deschutes River - CO is } \\
\text { more than the } \\
\text { Deschutes }\end{array}$ & $\begin{array}{l}\text { Deschutes } \\
\text { River }\end{array}$ & \\
\hline $\begin{array}{l}\text { Deschutes River - } \\
\text { Deschutes River is } \\
\text { Different/Special }\end{array}$ & $\begin{array}{l}\text { Deschutes } \\
\text { River }\end{array}$ & \\
\hline $\begin{array}{l}\text { Deschutes River - } \\
\text { Different Perceptions of } \\
\text { River Health }\end{array}$ & $\begin{array}{l}\text { Deschutes } \\
\text { River }\end{array}$ & \\
\hline
\end{tabular}




\begin{tabular}{|c|c|c|c|}
\hline $\begin{array}{l}\text { Deschutes River- } \\
\text { Attracts People }\end{array}$ & & $\begin{array}{l}\text { Deschutes } \\
\text { River }\end{array}$ & \\
\hline Deschutes River- & $\begin{array}{l}\text { Things like } \\
\text { "Lifeblood of } \\
\text { Central }\end{array}$ & Deschutes & \\
\hline Central to Basin Identity & & River & \\
\hline $\begin{array}{l}\text { Deschutes River- } \\
\text { Recreation \& Habitat }\end{array}$ & & $\begin{array}{l}\text { Deschutes } \\
\text { River }\end{array}$ & \\
\hline Deschutes River- & & Deschutes & \\
\hline Recreation is Secondary & & River & \\
\hline Different Recreation & & & \\
\hline Priorities & & & \\
\hline $\begin{array}{l}\text { DwC - Differing } \\
\text { Expectations }\end{array}$ & & $\begin{array}{l}\text { Difficulties } \\
\text { with } \\
\text { Collaboration }\end{array}$ & \\
\hline & & $\begin{array}{l}\text { Difficulties } \\
\text { with } \\
\text { Collaboration }\end{array}$ & $\begin{array}{l}\text { HCP } \\
\text { Stakeholders } \\
\text { - Who } \\
\text { Should vs } \\
\text { Who Was }\end{array}$ \\
\hline DwC - Power Imballance & & & \\
\hline DwC - Slow Process & & $\begin{array}{l}\text { with } \\
\text { Collaboration }\end{array}$ & \\
\hline $\begin{array}{l}\text { DwC - Specific Goals vs } \\
\text { Large Changes }\end{array}$ & & $\begin{array}{l}\text { Difficulties } \\
\text { with } \\
\text { Collaboration }\end{array}$ & \\
\hline $\begin{array}{l}\text { DwC - Too Many } \\
\text { Voices, Not Enough } \\
\text { Results }\end{array}$ & & $\begin{array}{l}\text { Difficulties } \\
\text { with } \\
\text { Collaboration }\end{array}$ & $\begin{array}{l}\text { HCP } \\
\text { Stakeholders } \\
\text { - Who } \\
\text { Should vs } \\
\text { Who Was }\end{array}$ \\
\hline DwC - Voices Left Out & & $\begin{array}{l}\text { Difficulties } \\
\text { with } \\
\text { Collaboration }\end{array}$ & $\begin{array}{l}\text { HCP } \\
\text { Stakeholders } \\
\text { - Who } \\
\text { Should vs } \\
\text { Who Was }\end{array}$ \\
\hline $\begin{array}{l}\text { DwC- Collaboration Just } \\
\text { Doesn't Work }\end{array}$ & & $\begin{array}{l}\text { Difficulties } \\
\text { with } \\
\text { Collaboration }\end{array}$ & \\
\hline DwC- Community Buy-in & & $\begin{array}{l}\text { Difficulties } \\
\text { with } \\
\text { Collaboration }\end{array}$ & \\
\hline
\end{tabular}




\begin{tabular}{|c|c|c|}
\hline $\begin{array}{l}\text { DwC- Falls Apart with } \\
\text { High Stakes }\end{array}$ & & $\begin{array}{l}\text { Difficulties } \\
\text { with } \\
\text { Collaboration }\end{array}$ \\
\hline $\begin{array}{l}\text { DwC- Individual Time \& } \\
\text { Effort }\end{array}$ & & $\begin{array}{l}\text { Difficulties } \\
\text { with } \\
\text { Collaboration }\end{array}$ \\
\hline DwC- Trust & & $\begin{array}{l}\text { Difficulties } \\
\text { with } \\
\text { Collaboration }\end{array}$ \\
\hline $\begin{array}{l}\text { DwC- Trust, } \\
\text { Interpersonal }\end{array}$ & & $\begin{array}{l}\text { Difficulties } \\
\text { with } \\
\text { Collaboration }\end{array}$ \\
\hline $\begin{array}{l}\text { Economic Sense of } \\
\text { Place }\end{array}$ & & $\begin{array}{l}\text { Different } \\
\text { Imaginaries } \\
\text { of Central } \\
\text { Oregon }\end{array}$ \\
\hline $\begin{array}{l}\text { Endangered Species - } \\
\text { Urgency }\end{array}$ & & $\begin{array}{l}\text { Irrigation } \\
\text { Districts, } \\
\text { Water } \\
\text { Rights, } \\
\text { Power }\end{array}$ \\
\hline $\begin{array}{l}\text { Endangered Species } \\
\text { Weren't the Concern }\end{array}$ & & $\begin{array}{l}\text { Irrigation } \\
\text { Districts, } \\
\text { Water } \\
\text { Rights, } \\
\text { Power }\end{array}$ \\
\hline $\begin{array}{l}\text { Environment has } \\
\text { Intrinsic Value }\end{array}$ & & \\
\hline ESA as a Rigid Tool & & $\begin{array}{l}\text { Irrigation } \\
\text { Districts, } \\
\text { Water } \\
\text { Rights, } \\
\text { Power }\end{array}$ \\
\hline $\begin{array}{l}\text { Evolvnig Recreation } \\
\text { Interests }\end{array}$ & & \\
\hline Ex-Urban Migration & & \\
\hline $\begin{array}{l}\text { Experiences in } \\
\text { Collaboration }\end{array}$ & & $\begin{array}{l}\text { INDEX } \\
\text { CODES }\end{array}$ \\
\hline GREAT QUOTE & & \\
\hline Greenwashing & $\begin{array}{l}\text { 11/9/20, 3:23 } \\
\text { PM, merged } \\
\text { with } \\
\text { Captured }\end{array}$ & $\begin{array}{l}\text { Irrigation } \\
\text { Districts, } \\
\text { Water }\end{array}$ \\
\hline
\end{tabular}




\begin{tabular}{|c|c|c|}
\hline & $\begin{array}{l}\text { NGOs } \\
\text { Including } \\
\text { things like } \\
\text { "Controlled } \\
\text { Narrative" }\end{array}$ & $\begin{array}{l}\text { Rights, } \\
\text { Power }\end{array}$ \\
\hline $\begin{array}{l}\text { HCP - Applicant Driven } \\
\text { Process }\end{array}$ & & $\begin{array}{l}\text { Habitat } \\
\text { Conservation } \\
\text { Plan }\end{array}$ \\
\hline HCP - Good Baseline & & \\
\hline HCP - Just a Baseline & & $\begin{array}{l}\text { Habitat } \\
\text { Conservation } \\
\text { Plan }\end{array}$ \\
\hline $\begin{array}{l}\text { HCP - Left Out } \\
\text { Recreation }\end{array}$ & & $\begin{array}{l}\text { HCP } \\
\text { Stakeholders } \\
\text { - Who } \\
\text { Should vs } \\
\text { Who Was }\end{array}$ \\
\hline HCP - Long Process & & $\begin{array}{l}\text { Habitat } \\
\text { Conservation } \\
\text { Plan }\end{array}$ \\
\hline $\begin{array}{l}\text { HCP - Necessary } \\
\text { Process }\end{array}$ & & \\
\hline HCP - Not Collaborative & & $\begin{array}{l}\text { Habitat } \\
\text { Conservation } \\
\text { Plan }\end{array}$ \\
\hline $\begin{array}{l}\text { HCP - Separate from } \\
\text { Collaborative Efforts }\end{array}$ & & $\begin{array}{l}\text { Habitat } \\
\text { Conservation } \\
\text { Plan }\end{array}$ \\
\hline $\begin{array}{l}\text { HCP - Substantial } \\
\text { Change }\end{array}$ & & \\
\hline $\begin{array}{l}\text { HCP - Tiers of } \\
\text { Collaboration }\end{array}$ & & $\begin{array}{l}\text { Habitat } \\
\text { Conservation } \\
\text { Plan }\end{array}$ \\
\hline $\begin{array}{l}\text { HCP-Good } \\
\text { Collaboration }\end{array}$ & & $\begin{array}{l}\text { Habitat } \\
\text { Conservation } \\
\text { Plan }\end{array}$ \\
\hline HCP-Inadequete & & $\begin{array}{l}\text { Habitat } \\
\text { Conservation } \\
\text { Plan }\end{array}$ \\
\hline $\begin{array}{l}\text { HCP- Leverage for } \\
\text { Environmentalists }\end{array}$ & & $\begin{array}{l}\text { Habitat } \\
\text { Conservation } \\
\text { Plan }\end{array}$ \\
\hline
\end{tabular}




\begin{tabular}{|c|c|c|}
\hline $\begin{array}{l}\text { HCP- Minimizing } \\
\text { Liability }\end{array}$ & $\begin{array}{l}\text { Habitat } \\
\text { Conservation } \\
\text { Plan }\end{array}$ & \\
\hline $\begin{array}{l}\text { HCP- Not a Big Deal for } \\
\text { Recreation }\end{array}$ & $\begin{array}{l}\text { Habitat } \\
\text { Conservation } \\
\text { Plan }\end{array}$ & \\
\hline $\begin{array}{l}\text { HCP- Process went } \\
\text { Black Box }\end{array}$ & $\begin{array}{l}\text { Habitat } \\
\text { Conservation } \\
\text { Plan }\end{array}$ & $\begin{array}{l}\text { HCP } \\
\text { Stakeholders } \\
\text { - Who } \\
\text { Should vs } \\
\text { Who Was }\end{array}$ \\
\hline $\begin{array}{l}\text { HCP- Started Big, but } \\
\text { Process Oriented }\end{array}$ & $\begin{array}{l}\text { Habitat } \\
\text { Conservation } \\
\text { Plan }\end{array}$ & $\begin{array}{l}\text { HCP } \\
\text { Stakeholders } \\
\text { - Who } \\
\text { Should vs } \\
\text { Who Was }\end{array}$ \\
\hline Importance to family & & \\
\hline $\begin{array}{l}\text { Improving } \\
\text { Environmental Quality }\end{array}$ & & \\
\hline $\begin{array}{l}\text { In-stream stakeholders } \\
\text { vs others }\end{array}$ & $\begin{array}{l}\text { Defining } \\
\text { Stakeholder }\end{array}$ & \\
\hline In-stream Water Rights & $\begin{array}{l}\text { Defining } \\
\text { Stakeholder }\end{array}$ & \\
\hline $\begin{array}{l}\text { Insiders vs Outsiders/ } \\
\text { Crowding }\end{array}$ & & \\
\hline $\begin{array}{l}\text { Irrigation Districts- } \\
\text { Couldn't Do It Today }\end{array}$ & $\begin{array}{l}\text { Irrigation } \\
\text { Districts, } \\
\text { Water } \\
\text { Rights, } \\
\text { Power }\end{array}$ & \\
\hline Landwatch & & \\
\hline Lawsuits & & \\
\hline Lawsuits!!! & $\begin{array}{l}\text { Irrigation } \\
\text { Districts, } \\
\text { Water } \\
\text { Rights, } \\
\text { Power }\end{array}$ & \\
\hline $\begin{array}{l}\text { Legal Geographies of } \\
\text { Water }\end{array}$ & & \\
\hline Lifestyle & & \\
\hline Lifestyle - Hobby Farms & & \\
\hline Many Different Rivers & & \\
\hline
\end{tabular}




\begin{tabular}{|c|c|c|}
\hline $\begin{array}{l}\text { Natural Flows vs } \\
\text { "Irrigation Ditch" }\end{array}$ & & $\begin{array}{l}\text { Different } \\
\text { Imaginaries } \\
\text { of Central } \\
\text { Oregon }\end{array}$ \\
\hline $\begin{array}{l}\text { Nature \& Recreation as } \\
\text { Comodity }\end{array}$ & $\begin{array}{l}\text { Extractive } \\
\text { nature of } \\
\text { tourism and } \\
\text { recreation }\end{array}$ & $\begin{array}{l}\text { Different } \\
\text { Imaginaries } \\
\text { of Central } \\
\text { Oregon }\end{array}$ \\
\hline \multirow{3}{*}{\multicolumn{3}{|c|}{$\begin{array}{l}\text { NGO's Overreaching } \\
\text { NGOs- Its a Small World } \\
\text { Occupational Situating \& } \\
\text { Positioning }\end{array}$}} \\
\hline & & \\
\hline & & \\
\hline \\
\hline Old Bend/New Bend & & $\begin{array}{l}\text { Different } \\
\text { Imaginaries } \\
\text { of Central } \\
\text { Oregon }\end{array}$ \\
\hline $\begin{array}{l}\text { Old Bend/New Bend - } \\
\text { Changing Powers }\end{array}$ & & $\begin{array}{l}\text { Different } \\
\text { Imaginaries } \\
\text { of Central } \\
\text { Oregon }\end{array}$ \\
\hline Outdoor Playground & & $\begin{array}{l}\text { Different } \\
\text { Imaginaries } \\
\text { of Central } \\
\text { Oregon }\end{array}$ \\
\hline $\begin{array}{l}\text { Percarious Recreation } \\
\text { Opportunites }\end{array}$ & & $\begin{array}{l}\text { Irrigation } \\
\text { Districts, } \\
\text { Water } \\
\text { Rights, } \\
\text { Power }\end{array}$ \\
\hline $\begin{array}{l}\text { Performing } \\
\text { Collaboration }\end{array}$ & & $\begin{array}{l}\text { Irrigation } \\
\text { Districts, } \\
\text { Water } \\
\text { Rights, } \\
\text { Power }\end{array}$ \\
\hline $\begin{array}{l}\text { Personal Investment in } \\
\text { Professional Work }\end{array}$ & & \\
\hline Political Polarization & & $\begin{array}{l}\text { Irrigation } \\
\text { Districts, } \\
\text { Water } \\
\text { Rights, } \\
\text { Power }\end{array}$ \\
\hline Positive Collaboration & & \\
\hline
\end{tabular}




\begin{tabular}{|c|c|c|}
\hline $\begin{array}{l}\text { Positive Collaboration - } \\
\text { Relationships }\end{array}$ & & \\
\hline $\begin{array}{l}\text { Positive Collaboration- } \\
\text { Outcomes }\end{array}$ & & \\
\hline Power Relationships & & $\begin{array}{l}\text { INDEX } \\
\text { CODES }\end{array}$ \\
\hline Preserving "Old Bend" & & \\
\hline $\begin{array}{l}\text { Prior Appropriation \& } \\
\text { ESA }\end{array}$ & & $\begin{array}{l}\text { Irrigation } \\
\text { Districts, } \\
\text { Water } \\
\text { Rights, } \\
\text { Power }\end{array}$ \\
\hline $\begin{array}{l}\text { Prior Appropriation is } \\
\text { Power }\end{array}$ & $\begin{array}{l}\text { 11/9/20, 3:23 } \\
\text { PM, merged } \\
\text { with } \\
\text { Irrigation } \\
\text { Districts } \\
\text { Refusing } \\
\text { Change }\end{array}$ & $\begin{array}{l}\text { Irrigation } \\
\text { Districts, } \\
\text { Water } \\
\text { Rights, } \\
\text { Power }\end{array}$ \\
\hline $\begin{array}{l}\text { Prior Appropriation- } \\
\text { Potential Changes? }\end{array}$ & & $\begin{array}{l}\text { Irrigation } \\
\text { Districts, } \\
\text { Water } \\
\text { Rights, } \\
\text { Power }\end{array}$ \\
\hline $\begin{array}{l}\text { Projected Sense of } \\
\text { Place }\end{array}$ & & \\
\hline $\begin{array}{l}\text { Public Awareness of } \\
\text { River Issues }\end{array}$ & & \\
\hline $\begin{array}{l}\text { Public Subsidies for } \\
\text { Irrigation }\end{array}$ & & $\begin{array}{l}\text { Irrigation } \\
\text { Districts, } \\
\text { Water } \\
\text { Rights, } \\
\text { Power }\end{array}$ \\
\hline $\begin{array}{l}\text { Real vs Not Real } \\
\text { Agriculture in CO }\end{array}$ & $\begin{array}{l}\text { Might merge } \\
\text { this with } \\
\text { Hobby } \\
\text { Farming }\end{array}$ & \\
\hline $\begin{array}{l}\text { Recreation \& Ag } \\
\text { Relationship }\end{array}$ & $\begin{array}{l}\text { Its both a } \\
\text { temporal and } \\
\text { a spatial } \\
\text { relationship. } \\
\text { They seem to } \\
\text { be the axis on }\end{array}$ & \\
\hline
\end{tabular}




\begin{tabular}{|c|c|c|}
\hline & $\begin{array}{l}\text { which the } \\
\text { culture in the } \\
\text { basin splits } \\
\text { across space? }\end{array}$ & \\
\hline $\begin{array}{l}\text { Recreation \& Basin } \\
\text { Identity }\end{array}$ & & $\begin{array}{l}\text { INDEX } \\
\text { CODES }\end{array}$ \\
\hline Recreation Accessability & & $\begin{array}{l}\text { Different } \\
\text { Imaginaries } \\
\text { of Central } \\
\text { Oregon }\end{array}$ \\
\hline $\begin{array}{l}\text { Recreation Building } \\
\text { "New Bend" }\end{array}$ & & \\
\hline $\begin{array}{l}\text { Recreation Central to } \\
\text { Basin Identity }\end{array}$ & & \\
\hline Recreation Variety & & \\
\hline $\begin{array}{l}\text { Recreation Will Happen } \\
\text { No Matter What }\end{array}$ & & \\
\hline $\begin{array}{l}\text { Recreators are } \\
\text { Environmentalists Too }\end{array}$ & & \\
\hline $\begin{array}{l}\text { Regulation and } \\
\text { Collaboration Collide }\end{array}$ & & $\begin{array}{l}\text { Irrigation } \\
\text { Districts, } \\
\text { Water } \\
\text { Rights, } \\
\text { Power }\end{array}$ \\
\hline Revolving Collaboration & $\begin{array}{l}\text { 11/9/20, 3:23 } \\
\text { PM, merged } \\
\text { with } \\
\text { Same Players } \\
\text { / New } \\
\text { Collaborative }\end{array}$ & $\begin{array}{l}\text { Irrigation } \\
\text { Districts, } \\
\text { Water } \\
\text { Rights, } \\
\text { Power }\end{array}$ \\
\hline River Mismanagement & $\begin{array}{l}\text { 11/9/20, 3:22 } \\
\text { PM, merged } \\
\text { with } \\
\text { Over- } \\
\text { Apportionment } \\
\text { \& Economic } \\
\text { Drivers } \\
\text { 11/9/20, 3:23 } \\
\text { PM, merged } \\
\text { with } \\
\text { Irrigation } \\
\text { Districts- }\end{array}$ & $\begin{array}{l} \\
\text { Irrigation } \\
\text { Districts, } \\
\text { Water } \\
\text { Rights, } \\
\text { Power }\end{array}$ \\
\hline
\end{tabular}




\begin{tabular}{|c|c|c|}
\hline & $\begin{array}{l}\text { Habitat } \\
\text { Destruction }\end{array}$ & \\
\hline \multicolumn{3}{|l|}{ Scarcity of Water } \\
\hline Sense of Place & & $\begin{array}{l}\text { INDEX } \\
\text { CODES }\end{array}$ \\
\hline $\begin{array}{l}\text { Stakeholder } \\
\text { Determination \& } \\
\text { Relationships }\end{array}$ & & $\begin{array}{l}\text { INDEX } \\
\text { CODES }\end{array}$ \\
\hline $\begin{array}{l}\text { Tensions with Prior } \\
\text { Appropriation }\end{array}$ & $\begin{array}{l}\text { 11/9/20, 3:23 } \\
\text { PM, merged } \\
\text { with } \\
\text { Tensions with } \\
\text { Prior } \\
\text { Appropriation } \\
\text { - Historical }\end{array}$ & $\begin{array}{l}\text { Irrigation } \\
\text { Districts, } \\
\text { Water } \\
\text { Rights, } \\
\text { Power }\end{array}$ \\
\hline The DBBC & & $\begin{array}{l}\text { Important } \\
\text { Actors }\end{array}$ \\
\hline The HCP & & $\begin{array}{l}\text { INDEX } \\
\text { CODES }\end{array}$ \\
\hline Unique Geomorphology & & $\begin{array}{l}\text { Different } \\
\text { Imaginaries } \\
\text { of Central } \\
\text { Oregon }\end{array}$ \\
\hline US Fish \& Wildlife & & \\
\hline $\begin{array}{l}\text { Wasted Water/ Flood } \\
\text { Agriculture }\end{array}$ & & $\begin{array}{l}\text { Irrigation } \\
\text { Districts, } \\
\text { Water } \\
\text { Rights, } \\
\text { Power }\end{array}$ \\
\hline $\begin{array}{l}\text { Water } \\
\text { Leasing/Markets/Trading }\end{array}$ & & \\
\hline
\end{tabular}

